This item was submitted to Loughborough's Research Repository by the author.

Items in Figshare are protected by copyright, with all rights reserved, unless otherwise indicated.

\title{
Foreign banks are branching out: changing geographies of Hungarian banking, 1987-1999
}

PLEASE CITE THE PUBLISHED VERSION

\section{PUBLISHER}

(C) Physica-Verlag

\section{VERSION}

AM (Accepted Manuscript)

\section{PUBLISHER STATEMENT}

This work is made available according to the conditions of the Creative Commons Attribution-NonCommercialNoDerivatives 4.0 International (CC BY-NC-ND 4.0) licence. Full details of this licence are available at: https://creativecommons.org/licenses/by-nc-nd/4.0/

\section{LICENCE}

CC BY-NC-ND 4.0

\section{REPOSITORY RECORD}

Jons, Heike. 2019. "Foreign Banks Are Branching Out: Changing Geographies of Hungarian Banking, 19871999". figshare. https://hdl.handle.net/2134/16217. 


\section{Please cite chapter as follows:}

Jöns, H (2001) Foreign banks are branching out: changing geographies of Hungarian banking, 1987-1999. In Meusburger, P and Jöns, H (eds) Transformations in Hungary: Essays in Economy and Society, Physica, Contributions to Economics, pp.65-124, ISBN: 3790814121 



\title{
Foreign Banks Are Branching Out: Changing Geographies of Hungarian Banking, 1987-1999
}

\author{
Heike Jöns
}

\section{Introduction ${ }^{1}$}

Walking through the streets of Budapest in spring 1999 could have given you the following impression: the supermarkets (Spar), the milk products sold there (Danone, Müller), and the property markets (OBI) come from different Western European countries such as the Netherlands, France and Germany. Almost all fast food restaurants (McDonalds, Pizza Hut, KFC) and many hotels (Hilton, Mariott) have their origins in the US; shoes and clothes offered in downtown are designed in Italy or France (Benetton, Marco Polo); medicine is predominantly produced in Switzerland (Novartis, Roche) and the banks as well as the car dealerships have their roots everywhere in the so-called Western world - usually including Japan and other Asian countries with major (car) companies - but not in Hungary itself.

In 1998, the ownership structure of the commercial banks, that are the main focus of this article, revealed a foreign share of almost $80 \% .^{2}$ Thus, the high amount of foreign direct investment (FDI) in the Hungarian banking sector fits the picture of a great openness towards foreign influences during the political-economic shift towards a market economy in Hungary. ${ }^{3}$ In 1999, about two years after the privatisation of the large state-owned commercial banks was completed, there were 25 commercial banks with FDI of more than $10 \%$ and only two commercial banks with FDI of less than $10 \%$. Just one commercial bank was fully privately Hungarian-owned. These commercial banks were all fiercely competing for corporate and private customers. Considering major concentration processes in Western European bank branch networks during the $1990 \mathrm{~s},{ }^{4}$ it seems to be a paradox that these market-experienced and often polyglot banks with representations in

1 This study was partly sponsored by the German Research Foundation (DFG) as part of Project ME 807/9-2. Regarding the process of writing this article, I would like to express my sincere gratitude to Janet Bojan for reading an earlier version of this text. Many thanks also to Aaron Steele for ironing out some English flaws at the beginning of this undertaking, and to Yvette Tristram for doing the same towards the end. I am responsible for any remaining ones. The conclusion owes much to discussions with Tim Freytag and Mike Heffernan. I am very grateful for their constructive and encouraging comments.

2 See section 2 and figure 2.

3 See HAMilton 1995, 81; JONES 1999.

4 See LEYSHON and THRIFT 1995; EUROPÄISCHE KOMMISSION 1999; and section 3.1. 
major global cities would have to spread their branch networks into small Hungarian towns in order to succeed in the face of tough competition. Surprisingly, this situation arose in Hungary at the end of the 1990s.

Why has this situation evolved? Who were the actors in the Hungarian banking market during the 1990s? Which business and branch network strategies have they followed? Which regions and which kinds of settlements were attractive for the banks? In which places have people or small and medium-sized enterprises (SME) benefited from access to the full range of banking services, and which places were neglected by the banks? What role have the banks played in the formation of a market economy in Hungary during the 1990s? And, finally, what can be concluded from the banks' network strategies and the theoretical framework of actor-network theory in regard to a theory of regional transformation? The aim of this article is to answer these questions and thus to contribute to a better understanding of the interrelation between banking and regional development during the first decade of political-economic transition from a centrally planned to a market economy in Hungary. In order to do so, this article will briefly recall the main steps of legal changes and examine three institutional developments during the 1990s in more detail:

- the number and types of financial institutions in operation;

- the ownership structure and business strategies of these institutions;

- the development of their branch networks.

In the first section, this study draws upon a broad range of literature concerned with the legal and institutional transformation of the Hungarian banking sector, and its competitive situation. ${ }^{5}$ The role of foreign-owned banks has been given special attention, ${ }^{6}$ including comprehensive analyses on the basis of geographical perspectives. ${ }^{7}$ Nevertheless, most studies focus on certain aspects of the legal and institutional transformation rather than relating different processes to each other. This is done to a certain extent by SZELÉNYI and URSPRUNG (1998) for the first decade of legal transformation of banking, but their main focus is on a yearly account of events. They do not analyse the dynamics of different interrelated processes over the whole period of time in detail, and do not include the spatial organisation of branch networks. Thus, different political, legal, institutional and spatial dynamics are woven together in the following and interpreted in regard to a theory of regional transformation in Hungary.

So far, only a few studies have paid closer attention to the role of bank branch networks for economic transformation in Hungary. ${ }^{8}$ In several aspects this study

\footnotetext{
See, for example, LENGYel 1994, 1995; BALASSA 1996; Botos 1998.

See, for example, Buch 1997; BusCH and WeISIGK 1997, JoNES 1999.

See KLAGge 1997a, 1997b.

See, for example, CSÉFAlvay 1994; IllÉs 1994; LENGYel 1994, 1995; JÖNS 1996, JöNS and KLAGGE 1997, KLAGGE 1997b.
} 
continues and extends these works, of which the last three include more detailed reviews of geographical research on banking in Hungary, elsewhere, and in general. For the most recent discussion of research on 'Transition and transformation' in post-socialist Europe conducted by geographers, see DINGSDALE (1999), FAßMANN (1999), HAMILTON (1999), and WARDENGA (2000).

The empirical work of this article is based on a database containing the branches of all credit institutions operating in Hungary between 1990 and 1999, ${ }^{9}$ and 24 semi-structured interviews conducted by the author in different banking authorities and banks (headquarters and branches) in Budapest, Györ, Székésfehervár and Békéscaba in spring 1996 (18) and spring 1999 (6).

\section{Legal framework and institutional development in the Hungarian banking sector since the 1980s}

The creation of a well functioning banking system is essential for the successful conversion of a centrally planned into a market economy. In Hungary, this was recognised very early. On January 1, 1987, Hungary was the first among the former socialist countries in Eastern Europe to restore the two-tier banking system typical of capitalist market economies. Within the socialist economic order, a Soviet-type one-tier system existed after a major restructuring of the banking system had taken place between 1947 and 1950. The dominant bank in this one-tier banking system, which was steered by the Ministry of Finance, was the National Bank of Hungary (NBH). It combined the functions of the former independent central bank and formerly competing commercial banks, keeping the accounts of all corporations in Hungary. In addition, there were four specialised financial institutions operating under the control of the NBH. Each financial institution held a monopoly for certain banking activities. ${ }^{10} \mathrm{~A}$ third element introduced in 1957 was

9 The database consists of information mainly drawn from the Hungarian Financial and Stock Exchange Almanac (see KEREKES 1990 etc.). This data was checked, completed and expanded by referring to Annual Reports of the National Bank of Hungary (NBH), the Hungarian Banking and Capital Market Supervision (HBCMS; including the former State Banking Supervision) and individual banks. The data for the period 1990 to 1996 was build up in collaboration with Britta Klagge (Hamburg).

10 See LENGYEL 1994, 382ff. The Országos Takarékpénztár (OTP) had the monopoly for dealing with private savings, loans and credits, and from 1972 onwards, with local governments as well. The Magyar Külkereskedelmi Bank (MKB) was responsible for financial transactions related to foreign trade, the State Bank for Development (SBD) for financing and supervising large investment projects arranged by the state. Before 1972 it dealt with building companies as well. The small Általános Értékforgalmi Bank (ÁÉB) was concerned with foreign accounts, claims and international property issues. 
constituted by small savings co-operatives, 263 of which were operating in $1980 .{ }^{11}$ While they were very active collecting private savings and granting household loans in rural areas, these co-operatives were bound by strong restrictions regarding their size, activities and networks. ${ }^{12}$

Competition between the financial institutions was completely prevented by a division of labour, regional restrictions and pre-set interest rates for loans and savings deposits. Thus, the activities of financial institutions were to a large extent mechanical. Due to the central control of the financial system, the supply of services was extremely limited as well. ${ }^{13}$ Generally speaking, banking was a medium for distributing state funds and redistributing private and corporate funds. ${ }^{14} \mathrm{Com}-$ pared with market economies, it played a completely different role within the framework of the centrally managed economy: Banking had almost no momentum and lacked significance in everyday life.

The move towards market principles came about at the end of the 1970s because the state was heavily in debt. Not only was Hungary in need of new capital for corporations, but, when the country joined the International Monetary Fund, the World Bank, and the International Finance Co-operation after a serious financial crises in 1982, it had to present new concepts on how to finance the deficit of the national budget. Moreover, Hungary had to promise that new loans would be allocated according to business principles. Finally, the growing number of legalised private enterprises during the 1980s led to a tremendous expansion of account management for corporate customers and made a decentralisation of the financial institutions necessary. ${ }^{15}$

As early as 1979, the Central-European International Bank (CIB) had been founded by the NBH and six foreign investors (major European and Japanese banks). CIB operated as a dollar-based bank with offshore status from January 1980 onwards, concentrating on foreign trade and currency transactions. ${ }^{16}$ Following this first step of institutional decentralisation, an average of two to three smaller specialised financial institutions were founded each year during the 1980s. These development funds and limited partnerships dealt mostly with small

11 See Lengyel 1994, 383. After World War II about 1000 co-operative banks operated in Hungary. They were liquidated in 1952 and were allowed again in the form of savings co-operatives in 1957 (see SzÖKE 1998, 584).

12 There was, for example, no competition between OTP, which was responsible for retail banking, and the savings co-operatives because of regional restrictions. OTP could maintain branches only in settlements with more than 5000 inhabitants, the savings cooperatives were only allowed to establish branches in settlements with less than 5000 inhabitants (see WASS VON CZEGE 1987, 411).

13 See BognÁR and ForgÁCs 1994, 53; ILLÉs 1994, 169. Securities were first introduced in 1983. Credit cards or check books were not used either (LENGYEL 1994, 383).

14 See, for example, WASS vON CZEGE 1987, 408f. However, in this respect it was "the most important tool in the indirect control of the economy" (LENGYEL 1994, 381).

15 See LeNGYel 1994, 382, 385; LeNGYel 1995, 112.

16 See KeREKES 1998, 181; KLAGGE 1997b, 158, 160. 
Hungarian enterprises, mainly financing the - often risky - development and launching of new products, and co-operation with foreign companies. ${ }^{17}$ In addition to the NBH, which was reorganised for the first time in 1985, when the central and commercial bank functions were separated, 19 financial institutions were operating in Hungary before the banking reform took place in $1987 .{ }^{18}$ The first regular bank with foreign direct investment (FDI) started operation in 1986 (Citibank), the second followed in 1987 (Unicbank).

During the 1980s, not only the number of financial institutions, but also the range of banking services increased. ${ }^{19}$ Nevertheless, it was already recognised at the beginning of the 1980s that the pressure on the financial system could not be remedied through a liberalisation of the one-tier banking system. Therefore, the government decided in favour of a market-orientated monetary policy and the establishment of state-independent relations between banks and enterprises. ${ }^{20}$

On January 1, 1987, the re-established two-tier banking system was organised as follows: The National Bank of Hungary (NBH) became the independent central bank, concentrating on monetary policy. The customers and branches of the former NBH lending department and parts of one specialised financial institution (SBD) were divided among three newly created institutions that became major non specialised commercial banks in the new system: Kereskedelmi Bank (K\&H), Magyar Hitel Bank (MHB) and Budapest Bank (BB). MKB and ÁÉB got commercial banking licenses in $1987 .{ }^{21}$ OTP received a commercial banking license in 1989 when its monopoly for retail banking was removed. The small financial institutions founded during the 1980s received either banking licenses, were liquidated or integrated into larger banks. The foundation of new credit institutions with or without FDI was welcomed, but, it was not until 1998 that the opening of foreign bank branches as legally independent institutions was allowed. The commercial banks operated as independent joint-stock companies and were allowed to act without regional or sectoral restrictions from 1989 onwards. The savings cooperatives continued to operate - like the already existing banks with FDI - and benefited from the revocation of the restrictions as well. The supervision of the banking market has been carried out by the State Banking Supervision since 1987.

17 See LENGYel 1995, 112; JöNS and KLAGGE 1997, 15. Bad debts of small enterprises are a main reason why small Hungarian-owned banks which had started as specialised financial institutions in the 1980s got major liquidity problems during the 1990s, and often had to be liquidated (see footnote 26).

18 These institutions were 14 small specialised financial institutions (LENGYEL 1995, 112) plus OTP, MKB, SBD, AÉB and Citibank (for the meaning of the abbreviations, see footnote 10).

19 See LENGYEL 1994, 385, and footnote 13.

20 See BognÁR and ForGÁCs 1994, 63; LENGYEL 1994, 385.

21 In order to support the newly founded banks, the former customers of the NBH were not allowed to change banks for the first six months in 1987, and only one bank had got a branch in each town (JöNS and KLAGGE 1997, 16; LENGYEL 1994, 386). 
Figure 1: Institutional development in the Hungarian banking sector, 1987-1999

Source: Author's compilation after Annual Reports of the National Bank of Hungary, the Hungarian Banking and Capital Market Supervision (including the State Banking Supervision), individual banks and KEREKES 1990, 1991, 1992, 1994, 1995, 1996, 1998. 
Along with the banking reform the first boom of new banks entering the market occurred in 1987. ${ }^{22}$ This boom marked the shift from a steady increase of financial institutions during the 1980s to an expansive rise (figure 1). By 1994 the number of credit institutions had increased to 44. This expansive period was based on slowly growing trust of foreign investors in the Hungarian banking sector due to the political transformation in 1989/90 and new legislation that aimed at fulfilling the conditions of a market economy of Western European style. The most important laws came into force in 1991 and $1992:^{23}$

- the Act on Credit Institutions outlining the operation of different types of credit institutions, safety regulations and banking supervision; ${ }^{24}$

- the Central Bank Act defining the tasks of the National Bank of Hungary;

- the Accounting Act primarily ruling banking activities;

- the Bankruptcy Act and the Act on Investment Funds.

Accordingly, 1991 showed the second boom in new banks entering the market. Another significant rise in the number of banks followed in 1993 when the bankruptcy, banking and accounting laws were amended for the first time. ${ }^{25}$

Compared with 1987, the banks starting operation in 1991 (7) and 1993 (5) were mainly foreign-owned and joint-venture banks. At the same time it became normal that an average of two to three banks per year had to be liquidated or to merge with other institutions. ${ }^{26}$ The reasons for the failure of these, mainly stateowned banks were combinations of bad assets inherited from socialist times, misconceptions of managers lacking market experience, negligent lending behaviour and obscure transactions, and the new regulations - above all the asset valuation system introduced in the Act on Credit Institutions. ${ }^{27}$ The latter had not only revealed the banks' bad asset portfolios but asked the banks to build up risk reserves for these. According to several doubtful and non-performing assets that were often related to state-owned enterprises and inherited from socialist times, many credit institutions had to set aside very high reserves and, thus, got serious capital, funding and portfolio problems. In order to remedy the financial problems of the

22 Six banks started operation in 1987.

3 See SZELÉNYI and URSPRUNG 1998.

24 See State Banking Supervision 1991a, 1991 b.

25 See NATIONAL BANK OF Hungary 1993, 159ff. Several adjustments were undertaken in the following years with regard to EU regulations (see footnote 33).

261991 saw the first bankruptcy of a specialised state-owned bank. In 1992, the first stateowned commercial bank had to be liquidated because the safeguarding criteria were no more fulfilled, while another bank of this type was taken over when WestLB entered the market.

27 In few cases the management had intended to make money themselves. SZELÉNYI and URSPRUNG $(1998,9)$ point out that an important phenomenon during the early years of the two-tier banking system was "the banks' and companies' concern to avoid initiating bankruptcy and liquidation proceedings against their debtors." This led to an accumulation of doubtful assets. 
majority of banks the government conducted consolidation programs for the banks and their debtors in 1992-93 and 1993-94. ${ }^{28}$ Although some smaller banks had to be liquidated and some mergers occurred as well, SZELÉNYI and URSPRUNG (1998, 8-9) regarded the consolidation process as being instrumental in ensuing adequate overall capitalisation of the banks in 1997 and thus having been "successful in solving the problems derived from the way in which the system was created and eliminating the consequences of the transformation crises." ${ }^{29}$

After the expansive period until 1994 the number of credit institutions fluctuated (figure 1): it decreased in 1995-1996, rose in 1997-1998 and declined again in 1999. In order to understand this development one has to take into account the different types of credit institutions that differ in organisational forms, ${ }^{30}$ the minimum amount of subscribed capital ${ }^{31}$ and their scope of activities: ${ }^{32}$

- (commercial) banks;

- $\quad$ specialised credit institutions;

- co-operative credit institutions (savings or credit co-operatives). ${ }^{33}$

28 See BALASSA (1996) and SZELÉNYI and URSPRUNG (1998, 9-10). The loan consolidation of 1992-93 included a bank-orientated loan consolidation and a enterprise-oriented loan consolidation at the banks. The bank consolidation of 1993-94 aimed at a recapitalisation of the banks.

29 At that time all the banks who survived were able to meet the required $8 \%$ minimum capital adequacy ratio (SZELÉNYI and URSPRUNG 1998, 8).

30 Banks and specialised credit institutions operate exclusively as public companies limited by shares (See STATE BANKING SUPERVISION 1997, 21).

31 Banks have to be established with a subscribed capital amounting at least HUF two billion and co-operative credit institutions need at least HUF hundred billion. The minimum amount of subscribed capital for specialised credit institutions depends on their activities (See STATE BANKING SUPERVISION 1997, 21).

32 Banks are permitted to pursue the full range of activities allowed for credit institutions; specialised credit institutions have the right to pursue some activities (the actual scope of activities depends on the individual license, but in total it is less than commercial banks can do). Co-operative credit institutions can do almost all the activities of the banks, but the actual scope of activities depends on the amount of the subscribed capital. In contrast to savings co-operatives, credit co-operatives are only allowed to deal except for currency conversion - with their own members (see STATE BANKING SUPERVISION 1997, 19).

33 These types are defined in Act No. CXII. of 1996 on the credit institutions and the financial undertakings (see StATE BANKING SuPERvision 1997). The Act on Credit Institutions of 1991 defined slightly different categories. At that time a specialised banking system of Anglo-American type was established. Commercial banks were not allowed to pursue certain financial institutional and capital market activities, such as offering and trading of publicly traded securities, investment trust management or insurance activities, in order to guarantee their prudential operation and to protect deposits (State BANKING SuPERvision 1991, 5f.). For meeting the requirements of OECD membership and EU harmonisation, a transition towards a universal financial system became necessary. Continuous modifications of the Act on Credit Institutions and the 
Responsible for reaching the 1994 maximum of 44 credit institutions again at the end of 1997 and 1998 was the slow but continuous increase of specialised financial institutions. Their growth in number accelerated in 1997 when two new types of financial intermediaries entered the market: building societies and mortgage credit institutions. The fact that these institutions, which provide long-term funds for households and businesses, were legally instituted ten years after the banking reform took place very well illustrates the time-consuming and step-by-step character of such a transformation process. ${ }^{34}$ The group of specialised credit institutions also includes one development bank and several specialised banks working in areas such as car purchase financing, consumer financing, export financing, investment facilities, reorganisation projects and regional development. This specialisation makes it more or less possible to do business without too much overlapping - although car purchase financing was already very competitive in 1998. Therefore, the present number of this kind of financial intermediary might continue to exist for the next few years.

A completely different situation developed in the commercial banking market that will be in the centre of the following analyses because commercial banks offer universal services to private and corporate customers using branch networks: ${ }^{35} \mathrm{At}$ the end of the 1990s, the commercial banks were fiercely contesting for customers in almost all segments of the market. The period of institutional expansion came to an end in 1994, and has been followed by a concentration process since then. Although new banks still entered the market, there have been more and more mergers and liquidations since the middle of the 1990s. Responsible for this are asset valuation and mismanagement (see above), an increasingly tough competition for customers in a difficult economic environment, and the government's effort to promote mergers and take-overs rather than the market entry of new banks because of the privatisation process. The institutional developments in 1996 very well illustrate the highly dynamic environment of the commercial banking sector in the second half of the 1990s: Two mergers occurred between state-owned banks

Securities Act served this transition during the 1990s. The types of credit institutions and their activities were modified along with these legal changes. The newly defined category 'specialised credit institutions' includes the Hungarian Development Bank (MFB), the Eximbank, the Land Credit and Mortgage Bank and the housing savings banks. All the other former specialised financial institutions had to be transformed into banks (NATIONAL BANK OF HUNGARY 1998, 73).

34 The legal bases are Act CXIII of 1996 on building societies and Act XXX of 1997 on mortgage credit institutions and mortgage notes (see HUNGARIAN BANKING AND CAPITAL MARKET SUPERVISION 1997, 15).

35 Almost all commercial banks have a branch network (see section 3). In 1998, only two specialised banks maintained three branches altogether, and two building societies had just started to establish a network of 17 consulting offices (KEREKES 1998). Many specialised banks offer their services through the branch networks of their parent company, such as OTP Building Society, or contract partners and thus do not need own branches. 
(Agrobank and Mezőbank, IBUSZ Bank and K\&H). ${ }^{36}$ A major part of state-owned Dunabank's infrastructure was acquired by the Dutch-owned ING Bank. The stateowned Iparbankház decided to withdraw from the market, MKBs privatisation was completed, and the subsidiaries of German-based Deutsche Bank and Dutch-based Rabobank started operation in 1996.

Altogether, the following processes triggered a major shift in the ownership structure of Hungarian banks:

- the liquidations of mainly small state-owned banks;

- the trend of state-owned banks merging into joint-venture or foreign-owned banks;

- the privatisation of state-owned banks; $;^{37}$

- the founding of new banks with FDI.

Figure 2: Ownership structure among commercial banks (as \% of total share capital)

Source: KEREKES 1998, 123-415; author's calculation.
In 1990, foreign ownership accounted for $26 \%$ of the commercial banks' aggregated share capital. By 1998 the respective number had risen to $79 \%$ (figure 2 ). At the end of 199015 of 26 banks were fully Hungarianowned and only two banks were fully foreign-owned. Eight years later the relation was exactly the other way around: two fully Hungarianowned and 15 fully foreignowned banks with 30 banks in operation. In 25 of these 30 banks foreign investors

36 These mergers, which were mainly based on the autonomous decision of the government as owner (SZELÉNYI and URSPRUNG 1998, 10), prepared the banks for privatisation in 1997 (Mezőbank was acquired by Erste Bank; a consortium formed by Irish life and Belgian Kredietbank became strategic investors in $\mathrm{K} \& \mathrm{H}$ ).

37 The privatisation of state-owned commercial banks began in 1990 with ÁÉB. At the end of 1997, this privatisation process was almost finished (NATIONAL BANK OF HUNGARY 1999b, 95). The situation of Postabank is special because of the run on the bank's funds in February 1997 which might have been triggered off by rumours about its financial situation (see, for example, Bank\&Tözsde VI (8), February 20, 1998). In order to save the important retail bank the state injected substantial financial aid. In $1998,63 \%$ of Postabank's share capital was directly owned by the state and the stateowned MFB (see footnote 33; total Hungarian shareholding was 92.3\%; KEREKES 1998, 374). 
hold the majority of shares, and at the end of 1999 there was only one fully Hungarian-owned bank left (the privately owned Konzumbank). Since another bank with more than $90 \%$ Hungarian shareholding is probably going to cease operation in 2000, ${ }^{38}$ Konzumbank, OTP and Postabank will be the last three commercial banks with Hungarian majority shareholding. In regard to the whole banking sector foreign ownership reached $60.4 \%$ of the aggregated share capital at the end of $1998 .^{39}$ This is an exceptionally high share by international standards, too. ${ }^{40}$

It is not easy to evaluate the dominance of foreign shareholding in Hungarian banks at the end of the $1990 \mathrm{~s} .{ }^{41}$ On the one hand, given the world-wide prevalent capitalist economic order at the dawn of the $21^{\text {st }}$ century, one could argue that the strong influence of foreign investors in the Hungarian banking system speeded up the development of a well functioning market economy. From this point of view the great advantage of FDI in the Hungarian banking sector results from the availability of sufficient capital. Corporations even benefit from promising conditions because joint-venture and foreign-owned banks undercut each other while fiercely contesting for customers, and these banks have the funds and the know-how to offer a wide range of high-quality services. Following this line of argument, the improved banking services have positive effects on corporations which in turn contribute to safeguarding jobs or even provide new jobs. Some would also argue that "the proliferation of foreign entities in Hungary has been a factor encouraging, even keeping under pressure, Hungarian-owned banks to improve the quality of their services, ${ }^{, 42}$ but this is not a very convincing argument, since there are not many Hungarian-owned banks left. On the other hand, one could argue that the banks' profits are not necessarily reinvested in Hungary because the majority of shareholders are foreigners. It is also doubtful whether the high-quality services are actually available to everyone, for example to Hungarian small and mediumsized enterprises (SME) or private individuals with medium or low income, and not only to joint-venture or foreign-owned companies and the high income strata of the population (see section 3).

However one would judge this aspect, fact is that during the first decade of the transformation process Hungarian-owned banks were almost completely ousted by joint-venture and foreign-owned banks because of their superiority regarding

- capitalisation;

- operational costs;

- $\quad$ no burden inherited from socialist times (non-performing assets);

38 Information received from the NBH in December 1999.

39 NATIONAL BANK OF HuNGARY 1999b, 95.

40 ERDEI 1998, 118.

41 For a summary of the pros and the cons regarding the market entry of foreign-owned banks in Hungary, see BUSCH and WEISIGK 1997.

42 SZELÉNYI and URSPRUNG 1998, 7. 
- technological standards;

- know-how and expertise;

- $\quad$ strategies (see section 3).

The process of institutional concentration among the commercial banks will probably continue in the first decade of the $21^{\text {st }}$ century. The low profitability of Hungarian banks may provide a further motive for concentration, ${ }^{43}$ and institutional concentration among banks is an international trend that is driven by the desire to take advantage of the economies of scale and can be observed in Western Europe as well. ${ }^{44}$ Experts consider about 20 commercial banks as the optimum for the Hungarian banking market. ${ }^{45}$

Among the savings co-operatives a concentration process can be observed since 1989. The number of savings co-operatives decreased from 262 in 1987 to 226 at the end of 1999 (figure 1). The number of mergers and liquidations increased in the second half of the 1990s because of the need to meet new capital requirements and problems of efficiency. This trend could not be compensated for by the founding of credit co-operatives from 1994 onwards. The savings co-operatives are very important for providing banking services in small villages (see section 3), but during the 1990s they were still characterised by low capitalisation, out-of-date technological standards, and a limited range of services. ${ }^{46}$ While institutional concentration among co-operative credit institutions will probably continue for some years due to undercapitalisation, their overall situation seems to improve a lot since a new National Federation of Savings Co-operatives was established in 1998 in order to deal with common concerns such as the representation of interests, training of member co-operatives, strengthening of the financial market position, nation-wide marketing activities and an enhancement of supervisory activity and external auditing of savings co-operatives. ${ }^{47}$

In summary, one can more or less agree with LENGYEL (1994, 381-82) when he states that for the first years of political-economic transformation, the early decentralisation of the banking system going hand in hand with a gradual disinte-

43 Hungarian BANKING ANd CAPITAL Market SuPERVISION 1998, 19.

44 See EuropäISCHE KOMMISSION 1999. Among the most prominent recent examples of institutional concentration in Western European banking are the mergers of Hypo- and Vereinsbank in Germany or Bank Austria and Creditanstalt in Austria.

45 Statements of Managing Directors at OTP Bank and Hypobank (interviewed in 1996), at Budapest Bank and the HBCMS (interviewed in 1999) (all interviews in Budapest).

46 In the first two decades of their operation, savings co-operatives essentially operated as non-profit organisations. Thus, they lacked sufficient resources to accumulate assets and substantial reserves. The formation of profit-related capital and reserves only began in the 1980s and developed quite slowly (SZÖKE 1998, 587).

47 SzÖKE 1998, 587. The first step towards the integration of savings co-operatives was the foundation of the Hungarian Bank of Savings Co-operatives, the first of three central institutions, in 1989. By the end of 1997, the number of integrated savings co-operatives was 227 . 
gration of the centrally planned economy contributed to a "relatively smooth transformation of the political system in Hungary." Nevertheless, looking at the past events from the perspective of the year 2000, the legal and institutional developments in the Hungarian banking sector have been quite turbulent during the whole decade after the political transformation, especially after 1994. While the institutional re-organisation will probably continue for some time, it seems to have required thirteen years after the banking reform for the major legal and institutional innovations to be almost completed: a legal framework orientated to EU standards, the establishment and monitoring of safety regulations for the banks' operation, the privatisation of state-owned banks, institutional decentralisation (in certain segments followed by concentration) and institutional diversification. Accordingly, SZELÉNYI and URSPRUNG (1998) differentiate 'three stages of progress' towards the political aim of a banking system typical for market economies:

- $\quad$ growth period (1987-91);

- period of consolidation (1992-94);

- stabilisation (1995-97).

Considering the different political, legal and institutional developments in detail, the first decade of the re-emerging Hungarian banking market can be characterised as shown in figure 3 . The following section adds further to these developments by analysing the banks' business and branch network strategies in regard to the nature of regional transformation and its significance for the banking sector.

Figure 3: Important developments regarding Hungarian banking, 1980-1999 


\section{Business activities and branch network strategies of Hungarian banks during the $1990 \mathrm{~s}^{48}$}

The development of bank branch networks in Hungary during the 1990s shows that more and more commercial banks established their own networks: While eight banks maintained at least one branch in 1987 (47\%), there were 24 banks with at least one branch in 1999 (83\%). The number of banks with large networks (at least 20 branches), rose from three to twelve banks in the same period of time (18\% to $41 \%$ ) (figure 1).

This development confirms that branch networks are very important elements in the business strategies of commercial banks. They enable the banks to get in contact with customers in places distant from the headquarter and to serve them all day long without too much effort for the clients. Acquiring clients in order to build up a customer base has, of course, top priority for almost all newly established commercial banks in the Hungarian banking market. The way they proceed depends in the first place on their main target groups. The size and business prospects of potential clients at different locations influence the basic decision whether it is profitable to establish a lot of costly branches or if it is sufficient to acquire and serve them in other ways (see section 3.1).

Thus, the first question to emerge is, which business and network strategies the individual banks followed, and how these strategies changed over time. From a geographical point of view, however, considering only the number and function of operative units is not enough to understand the development of the Hungarian banking sector during the 1990s. Based on the empirically and theoretically well founded fact that 'space makes a difference', ${ }^{49}$ it can be assumed that the specific setting of a place does not only influence the decision where to open a branch, but its operation and profitability as well. Therefore, the spatial organisation of the branch network would have effects on the operation of a bank as a whole. The interrelation of business strategies, networking (regarding the number, functions and locations of branches) and the banks' profitability raises two further questions:

48 As indicated before, the focus of the following analysis will be on those banks who operated as commercial banks before 1996. In 1996 and 1997, new legislation laid down that former specialised financial institutions would have to be transformed into 'banks' during the next years (NATIONAL BANK OF HuNGARY 1998, 73). The concentration on the commercial banks is reasonable for the 1990s because they have been offering universal services to private and corporate customers, most of them using a branch network. While differing to a greater extent from specialised financial institutions, their kind of operation is basically comparable. Among the specialised financial institutions only Corvinbank, which merged with Konzumbank in 1997, had maintained a branch network for some years (six branches in 1996). In 1999, the building societies, Porsche Bank (two branches) and Rákóczi Bank (one branch) had at least one operative unit in addition to their headquarters (see footnote 35 as well).

49 See, for example, MASSEY 1984 
Where have the newly established banks opened their branches, and how have the banks that inherited networks from socialist times reacted in time and space after the market came politically and legally into being?

Analysing the banking sector in the emerging Hungarian market economy from a spatial perspective does not only offer insight into the development of the banking sector as a driving force for the kind of market economy Hungary has been striving for, but for regional development as well:

- The presence and absence of bank branches express current regional disparities in economic development because market-experienced banks strive to open their branches only in places that seem to be profitable, which usually is the case in economically prosperous regions.

- Bank branches can also be regarded as indicators of future development opportunities: The local presence of a bank branch facilitates the provision of loans, capital investments and important information about business opportunities for residents and SME. In this way, bank branches foster consumption and investments in a region and thus potentially contribute to further economic development. ${ }^{50}$ Since the absence of bank branches has opposite effects, "geographical variations in access to the financial system deepen and accentuate prevailing levels of uneven development."

- Since banks belong to the basic institutions of a market economy and are characterised by the above dialectic of expressing and contributing to regional development, the density and type of branch networks partly reflect the current stage of the economic transformation process.

Although the mere distribution of bank branches indicates whether people and SME at certain places could have access to a broader supply of banking services in general, the conditions under which the services are offered and their quality have also to be examined in order to differentiate who could actually benefit from certain kinds of bank branches. ${ }^{52}$ Based on these considerations the actors among Hungarian commercial banks during the 1990s will now be characterised in more detail by studying their business and network strategies and analysing the corresponding regional organisation of their networks, including alternative financial infrastructure.

\subsection{Competitive advantages, business activities and the size of networks}

One of the basic processes regarding institutional development during the 1990s was the spreading out of foreign ownership in the Hungarian banking sector ('for-

50 See KLAGge 1995; LeYSHON and THRIFT 1995.

51 DYMSKI and VEITCH 1992 quoted in LEYSHON and THRIFT 1995, 315.

52 See JÖNS 1996. 
eignisation'). Accordingly, the ownership structure can be identified as an important aspect for characterising the institutional actors in this period of time. Recalling the competitive advantages of banks founded with FDI, it becomes obvious that the banks with FDI were in many respects superior from the beginning of their operation. In regard to business strategies, those banks that started operating in socialist times had to deal with customers they acquired at that time or inherited from former institutions. These customers were often large unprofitable corporations and clients from crises-prone sectors. In contrast, banks with FDI could concentrate on highly profitable fields of activities and respective customers (such as sound joint-venture and large companies, private banking). They were also able to plan the number, size, function and location of their branches strategically, while most of the Hungarian-owned banks had to deal with branch networks that were built up on the basis of completely different criteria than those important in a highly competitive environment, for example, with regard to the technical background of the branches or the branch locations.

Therefore, banks founded without FDI (I) and those founded with FDI (II) have to be differentiated when analysing the Hungarian banking market in the 1990s. Additionally, the banks founded without FDI can be differentiated in the former large state-owned banks (I-1) and medium and small banks founded without FDI (I-2). The banks in these groups differ substantially in regard to capitalisation and customer base and thus their scope of activities. Since a lot of the Hungarianowned banks were partly or completely acquired by foreign investors in the course of privatisation, a final differentiation will be made between those banks who stayed Hungarian-owned (I-1a and I-2a) and those which attracted foreign investors (I-1b and I-2b). The latter were able to benefit from the competitive advantages related to foreign direct investments and market expertise (before 1996 all foreign investors had come from established market economies). ${ }^{53}$

This classification of Hungarian banks, which was basically adopted from JöNS and KLAGGE (1997) is most useful for systematising the different institutional actors in the 1990s. Accordingly, the numerical development of the different types of banks very well illustrates the ousting of Hungarian-owned banks by banks founded with FDI that dominated at the end of 1999 (figure 4). The acquisition of Hungarian-owned banks by foreign investors, which started in 1989 among small and medium-size banks and in 1994 among the large banks, was forced through the privatisation process and lead to the second (I-2b) and third (I-1b) largest groups of banks in 1999. The fact that just one of 29 commercial banks had no FDI in 1999 indicates that the ownership structure was a suitable criterion for the classification of banks in the first decade after the political transformation. In future, other aspects will have to serve for differentiation. Those criteria, as the

53 In 1996 a Russian bank bought 100\% of ÁÉB. 
analysis will show, are the size of commercial banks and their market share in different segments of the market.

Figure 4: Commercial banks by ownership structure, 1987-1999

I: banks founded without FDI; I-1: former large state-owned banks; I-2: medium-sized and small banks; I-1a and I-2a: Hungarian-owned banks; I-1b and I-2b: banks acquired by foreign investors; II: banks founded with FDI

Source: See figure 1; author's compilation.

Figure 5: Bank branches of commercial banks by ownership structure, 1987-1999

Source: See figure 1; author's compilation; for legend see figure 4. 


\subsubsection{Bank branch network developments}

The development of the total number of Hungarian bank branches and the proportions of the different types of banks (figure 5) show that almost all operative units belonged to the large state-owned banks in 1987. While their number of branches fluctuated in the 1990s, the branch networks of small and medium-sized Hungarian-owned banks gained greater importance between 1991 and 1995, but decreased afterwards - parallel to the mergers, acquisitions and liquidations - to almost zero in 1999. The first banks founded with FDI started to open branches in 1990. The pace of the growth of their networks accelerated substantially at the end of the 1990s. For example, the number of branches operated by these banks grew about more than 2.5 times in 1998, and increased by another $20 \%$ in 1999 . These developments and the fluctuating number of branches in total - increase until 1992, decrease in 1993-94, expansion in 1995 followed by a slight reduction in 1996-97 and another increase in 1998-99 - are the results of different developments that can only be identified by referring to the business and network strategies of the individual banks. It can only be stated by now that the high concentration of branches among the four former state-owned large banks - maintaining $57 \%$ of all branches in 1999 - seems to be a competitive advantage in the highly competitive environment at the end of the 1990s. This is because large networks guarantee such a high proximity to customers that can only be reached slowly by the banks which have to build up new networks. Whether the relatively slow pace of network development among the banks founded with FDI (type II) mirrors a disadvantage or is rather intended by the subsidiaries of market-experienced actors will become clear in the following paragraphs.

Considering the branch network development of individual banks between 1987 and 1999 (figure 6), the following types of banks can be identified by their networks: ${ }^{54}$

- Banks with networks since 1987. These banks were all state-owned before the middle of the 1990s and were then either privatised or taken over by foreignowned banks (I-1 and I-2). All the respective networks continued to exist until 1999, but were modified in between.

- Banks that established networks either before the political transformation or afterwards, but which ceased to exist until 2000 (I-2a). All but one were medium or small state-owned banks characterised by undercapitalisation and accumulated bad debt. They either merged with other state-owned institutions as a preparation for privatisation, were partly taken over by other banks or liquidated. The exception is Takarékbank, the Bank of the Savings Co-operatives, which was privatised and continues to exist, but closed down its branches until 2000 .

54 The statements about events in 2000 rely on personal information given by a banking expert (NBH) in December 1999. 
- $\quad$ Banks that founded the first branches either in 1988 (one bank) or after 1990 (the rest) and have been expanding their networks in the second half of the 1990s (EKB merged with Citibank in 1999). They are all banks with FDI, although some banks were founded without FDI and partly or completely acquired by foreign investors later on (I-2b and II). ${ }^{55}$

At the end of 1987, OTP had the largest network by far due to its long monopoly of retail banking (429 branches). OTP was followed by the three banks created from the lending department of the NBH: K\&H (51 branches), MHB (23 branches), BB (18 branches). All the other banks maintained fewer than ten branches. After the retail market segment was opened up for all commercial banks in 1989, OTP reduced its network by $13 \%$ until 1995 while almost all the other banks (I-1a and II-2a) extended their networks substantially until 1992. This first period of network expansion can be described as 'market euphoria' in which the banks strove for regional presence in order to get in contact with potential clients. ${ }^{56}$ OTP, starting from a incomparably high basis, used the time for a reduction of the costly network, resembling the trend that could be observed in several Western European countries at that time. ${ }^{57}$

Between 1992 and 1995 the network expansion either stopped (Mezöbank, Konzumbank, MKB, Dunabank) or slowed down in almost all banks, some even reducing their number of branches again (K\&H, MHB, Iparbankház). Responsible for this trend was a combination of different aspects: the portfolio crises (consolidation programs between 1992 and 1994) and related cautious business policies on the part of the banks; extremely high costs for establishing and even maintaining branches due, for example, to a high number of employees inherited from socialis times or the renewal of obsolete technical background; the influence of 'smallnetwork' strategies announced by the banks with FDI at that time. Originally, the banks founded with FDI had planned to concentrate on highly profitable business activities such as the financing of multinationals, large joint-venture and Hungarian-owned companies and private banking and thus to serve a rather élite clientele from few branches in the major urban centres.

Nevertheless, a second period of network expansion began in the second half of the 1990s, based on the already large and medium-sized networks growing once more. In addition, the newly established networks of banks with FDI showed an accelerating growth. This development was favoured by the fact that at that time, the consolidation programs were finished, the need for provisions continued to diminish, ${ }^{58}$ the number of commercial banks had reached its maximum and thus the competition had grown immensely. More and more banks with FDI set up

For the exception of Postabank, see footnote 37.

56 See JÖNS and KLAGGE 1997.

57 See, for example, LEYSHON and Thrift 1995; EUROPÄISCHE KOMMISSION 1999.

58 SZELÉNYI and URSPRUNG 1998, 32. 
22 H. Jöns

Figure 6: Branch network development of individual banks, 1987-1999

$\mathrm{L}=$ Large bank; $\mathrm{M}=$ Medium-sized bank; $\mathrm{S}=$ Small bank. For an explanation of the different types of banks (such as I-1b), see figure 4 . Years in brackets indicate the date of acquirement by foreign investors. 
Source: See figure 1; author's compilation. 
branches and became strong competitors for the Hungarian-owned banks outside Budapest, especially because of sophisticated products and high standards regarding service and technology. The battle for customers in the corporate segment strengthened so much that the banks started to look for alternative business opportunities in still more concentrated segments. Additionally, it had become clear among banks with FDI that liquidity for corporate financing is limited, and deposit taking one possibility to raise funds. Therefore, several banks reformulated their strategy and aimed at gradually increasing their presence in certain segments of the retail market as well as in lending to creditworthy small and medium-sized businesses by opening more new branches than originally planned. ${ }^{59}$ Thus, an expanded branch network became an important competitive advantage in the race for spatially less concentrated customers.

Remarkably, the network expansion of the former state-owned large banks followed in each case the take over by foreign investors. This supports the observation of other authors that banks and companies with FDI have been very flexible and active in opening up new markets during the transformation process in Central Europe ${ }^{60}$ Thinking of the first period of network extension until 1992, which was backed by the state-owned banks, this flexibility and activity seems to depend to a high extent on sufficient funds and not so much on market experience per se. Postabank started the second period of network extension by opening 219 agencies in 1995. These agencies are not fully-fledged branches, but offer basic retail services in addition to the branches. In 1996, the other banks followed suit: OTP, which was just privatised, intended to secure and widen its large branch network that has been identified as a major competitive advantage in the second half of the 1990s. The efforts to maintain its market leader position as the largest retail bank in Hungary had to be enhanced because of other commercial banks' new ambitions in the retail market. Furthermore, the savings co-operatives announced the goal to double their market share within the next five years in $1998 .{ }^{61} \mathrm{~K} \& \mathrm{H}$ extended its network through the merger with the retail-orientated IBUSZ Bank, while Mezőbank, Konzumbank and MKB are further examples of banks that joined the second period of branch network extension by opening new branches.

Among the banks with FDI the expansion of networks substantially accelerated in 1998-99 when CIB and ING started their offensives to become major players in the retail market. Six additional banks with FDI named the retail segment and

59 See 'strategy and future plans' of the individual commercial banks in KEREKES 1998, for example, pages 183 and 284. According to interviewees and JONES (1999, 42-43), the banks' strategies of "seeking out new retail deposits and cultivating the small business lending markets in the hunt for new businesses" resulted mainly from narrowing profit margin after blue-ship companies used the possibility to play off several client banks.

60 See, for example, Busch and Weisigk 1997, 907; HAMILTON 1999, 140.

61 See the strategy and future plans of Takarékbank in 1998 (KEREKES 1998, 152). 
network development top priorities for the coming years when asked in $1998 .^{62}$ For example, Raiffeisen Unicbank stated that it aims at a network of 50 branches in 2001, while ABN AMRO Bank, which acquired MHB in 1998, aims to develop a network of 120-150 branches until 2001. ${ }^{63}$ Although most banks founded with FDI ( $62 \%$ of all commercial banks) changed their overall business and network strategies at the end of the 1990 s, their proportion of branches reached only $26 \%$ at the end of 1999. After branches were identified as a major competitive advantage, the growth of branch networks accelerated, but the process of network development still seems to be a rather time consuming process. At this stage of the analysis it can just be assumed that money is not the only restrictive factor for network development among the foreign-owned banks. Later it will be shown that that the local circumstances existing at potential branch locations play an important role for the development of the bank branch networks (see section 3.2).

\subsubsection{The development of business activities and market shares}

The branch network developments of the individual commercial banks are strongly interrelated with the number of banks, their business activities and market shares. The corporate sector was contended at first because of much better business prospects than in the retail sector. The retail market attracted considerable attention as an opportunity to widen the banks' market share only when the number of commercial banks reached the maximum in the middle of the 1990s and more and more banks with FDI started to build up their own branch network in order to serve corporate clients. According to these developments the concentration of credit portfolio in the highly contended corporate sector was not high anymore at the end of the 1990s, while the retail market shares have just begun to become decentralised. The lending business to households has even just began to develop then (figure 7). ${ }^{64}$ In 1997, OTP, the savings co-operatives and Postabank together still held $67.5 \%$ of the market shares in the household liabilities market, although their share was further declining compared to previous years. ${ }^{65}$ Concerning the underdeveloped household lending sector, the concentration was extremely high in certain segments. For example, $95 \%$ of all housing credit was disbursed by OTP and savings co-operatives, while $97 \%$ of consumer loans were made by four credit

62 See KEREKES 1998.

63 See KeREKes 1998, 128, 400

64 Retail services have been mainly concentrated on deposit taking, current account management and bank card services in the second half of the 1990s, while loan facilities to households - like loan facilities for small businesses in the corporate market - were still underdeveloped at the end of the 1990.

65 The Hungarian BANKING AND CAPITAL MARKET SuPERVISION $(1998,25)$ points out that in 1997 nearly half of all credit institutions increased the share of household liabilities in their liability structures, but that the share of household liabilities was still below $10 \%$ among the liabilities of seventeen banks. 
institutions and the savings co-operatives. ${ }^{66}$ Altogether, primarily large and small banks have been active in the household market so far. In case of the mediumsized banks their proportion of the aggregated balance sheet is only reflected in the corporate market where they have been underscoring each other with offering the lowest interest rates for years. Although still $44 \%$ of all corporate loans were extended by four large banks in $1997,{ }^{67}$ "it was corporate financing where the most credit institutions participated in activities exceeding their market shares based on asset size. ${ }^{168}$ Concentration on corporate deposits was much less than in the household market, too. ${ }^{69}$

As another result of the intensive competition, more and more medium-sized businesses got loans from the banks in the second half of the 1990s while the banks' business policy towards small companies is still rather reserved because of the risk involved. ${ }^{70}$ The increasing engagement in lending to medium-sized and small companies at the end of the 1990s was not only encouraged by competition, but by the government as well. In order to support the underdeveloped SME sector in Hungary, the latter "is offering to pay up $70 \%$ of the interest on bank loans to small firms," ${ }^{71}$ but, nevertheless, a considerable credit risk still lies with the lending bank. Thus, financing small businesses will probably be one of the last segments of commercial banking that tight competition for market shares will go into. In order to win small businesses as customers, a large branch network will be a competitive advantage again.

Altogether, the concentration in the banking sector no longer counts as high in a European context since $1997 .^{72}$ To a considerable extent this can be put down to the expansion of almost all medium-sized banks. ${ }^{73}$ In contrast, the group of small banks consists of much more heterogeneous institutions. Some have been producing extraordinary growth while others have hardly grown or even declined at the end of the 1990s. ${ }^{74}$ A general problem of the Hungarian banking sector is still the banks' capitalisation that is rather low in international comparison. This becomes evident especially regarding the capital requirement of certain infrastructural investment projects in Hungary. ${ }^{75}$ The low capitalisation might as well pro-

66 Hungarian Banking ANd CAPITAl Market Supervision 1998, 25.

67 HUNGARIAN BANKING AND CAPITAL MARKET SUPERVISION 1998, 28.

Hungarian BANKING AND CAPITAL MARKET SuPERVISION 1998, 30.

See Hungarian BANKING AND CAPITAL MARKET SUPERVISION 1998.

See NATIONAL BANK OF HUNGARY 1999 b.

JONES 1999, 42.

72 NATIONAL BANK OF HUNGARY 1998, 74.

See NATIONAL BANK OF Hungary 1999b, 95.

74 NATiONAL BANK OF HuNGary 1998, 74.

75 According to the Hungarian BANKING ANd CAPITAL MARKET SuPERVISION $(1998,59)$ the maximum amount of syndicate loan all Hungarian banks seen as a consortium could extend to a client without violating the relevant legal restrictions would be HUF 115 billion (= combined large risk assumption limit). Thus, their financing is impossible without co-operation between Hungarian and international banks or banking groups in 
vide another reason for ongoing institutional concentration among commercial banks in the future.

Figure 7: Volume and market shares of credit institutions in the household and corporate sector market at the end of $1997^{76}$

Source: Hungarian BANKING AND CAPITAL MARKet SuPERVISION 1998, 23-30; author's compilation.

\subsubsection{Future business and branch network strategies}

At the end of the 1990s, the following banks can be differentiated by their business and branch network strategies:

- large banks who try to become a major player in all segments of the corporate and retail markets (including the mass market), and already maintain or strive for a large network with more than 80 branches;

- those banks who pursue broad activities in the corporate market, and, besides, aim at a reasonable stake in the more attractive segments of the retail market with establishing 50 to 80 branches;

- other banks who concentrated on foreign-owned, joint-venture and sound Hungarian-owned enterprises so far (often serving as second or third client bank), but have been trying to open up towards SME and private individuals with medium or high incomes recently. They aim at 25-30 branches, which is more or less equivalent to the number of counties in Hungary. Only a few banks continue to have their focus exclusively on corporate banking.

consortia offering syndicate loans.

76 In this statistics the banks are classified according to its shares in the adjusted size of the sector (including specialised credit institutions, but not building societies): large banks: above 3\%; medium-sized banks: between 1-3\%; small banks: below $1 \%$. The National Bank of Hungary defines slightly different categories. 
In addition to the continuous development of the banks' branch networks for client acquisition both in corporate and retail market, other common business policy objectives named by the banks in 1998 as their 'future and business plans' were the following: ${ }^{77}$

- widening of the bank's retail product range (retail loan facilities etc.),

- developing investment banking facilities,

- enhancing the profitability and efficiency of the operative units,

- installing an integrated information technology infrastructure,

- training employees.

Many banks also have been providing or are developing direct banking services such as home and phone banking facilities; however, the recent trend in network development underlines that at the current stage of the transformation process local branches have a greater importance for acquiring business clients and private individuals than IT facilities. A major characteristic of the transition period is that banks have to make people trust in market-orientated banking activities, and this is best and mainly achieved through personal interaction. How fragile the environment still was at the end of the 1990s demonstrated the liquidity crises at Postabank in 1997 that resulted from a run on the banks funds. Nation-wide, people queued in Postabank branches in order to take their money out of the bank after rumours about financial problems had come up. ${ }^{78}$ Direct banking facilities are, of course, a major competitive advantage after clients have been acquired and are more confident with the business opportunities offered by banks in a market economy (see section 3.2). Those commercial banks that do not have a branch network as yet or just maintain fewer than five branches are mostly small banks focusing on corporate business in certain sectors such as energy, transport and telecommunication, food, wholesale and retail business, or on financing bi- or multilateral activities between Hungary and certain regions such as ASEAN countries or countries in Western Europe. Banks operating on this basis are, for example, ÁÉB, Rabobank, and Hanwha Bank.

\subsubsection{Summing up alternating waves of expansion and reduction}

Regarding the quantitative development of bank branch networks in Hungary since 1987, the following main phases can be distinguished:

- a 'market euphoria' until 1992 as the first period of network extension; this was dominated by the activity of Hungarian-owned banks; between 1987 and 1992 the total number of branches increased by $80 \%$;

- a period of network reduction in 1993-94 due to the effects of the portfolio crises and high operational costs of branch networks; a stagnation in network

77 See KeREKES 1998.

78 See footnote 37. 
development or a reduction of branches occurred at almost all Hungarianowned banks, while banks with FDI started to build up their networks; the total number of branches was slightly reduced in 1993 and 1994;

- a period of 'reduction versus expansion' between 1995 and 1997 caused by four overlapping processes: the continuing cautious network policies and reduction of branches among Hungarian-owned banks in 1995, mergers and liquidations among commercial banks with branches as well as the following reorganisation of enlarged networks through mergers, the beginning of a second period of network extension, encouraged by Postabank in 1995, and, finally, the steady opening of new branches by banks with FDI;

- a second period of network expansion becoming manifest in 1998 and even accelerating in 1999; this time the spreading out of branches was stimulated by growing competition for customers even beyond the most attractive clientele from the corporate sector, including more risky corporate lending activities, such as financing medium-sized and small companies, as well as different segments of the retail market; after a further reduction of branches among Hungarian-owned banks in 1998-99, there was only one Hungarian-owned bank left at the end of 1999 (which was privately owned).

One of the most eye-catching phenomenon in the above analysed branch network development is the fact that the Hungarian-owned banks were not able to use their advantage of large networks, which was even extended during the period of 'market euphoria': facing a growing competition of banks with FDI they had not enough time to build up a deficit in funds as well as operational skills and get rid of the obsolete technical background. ${ }^{79}$ Only privatisation, which meant an increasing influence of foreign investors and improved financial bases, made the further extension of branch networks and thus the restoring of the former competitive advantage in those banks possible - mainly because of sufficient capital for bearing the high costs of network development.

Among the savings co-operatives, a similar trend to the network development of commercial banks can be observed: despite continuing institutional concentration since 1987 the number of co-operative branches decreased until 1995 and has been expanded again since then (1990: 1771 branches; 1995: 1658 branches; 1997: 1 757 branches).$^{80}$ This observation reinforces the conclusion that alternating waves of expansion and reduction are a major characteristic of individual and aggregated bank branch network developments during a period of economic transformation. They occur because banks are continuously operating in an area of conflict between customer acquisition and reduction of the operational costs. The shifts in

79 This is true for the privatisation of banks as well: in Hungary itself, there was not enough time to build up capital in order to take over more than one state-owned bank with privately owned Hungarian capital. The pressure of well-capitalised foreign investors invading the market was too high.

80 Author's calculation according to KEREKES 1991, 1996, 1998. 
network strategies, that are accelerated by changes in the competitive environment, are based on the fact that the profitability of a branch is not completely predictable. Instead, it has to be experienced through business practice, and this identifies the bank branch network development as an process of trial and error. This does not only lead to the assumption that the changes in the size of individual branch networks will probably stay as dynamic as they were in the last ten years for at least another decade. It also raises the question whether such waves of expansion and reduction can be observed in established market economies as well? Although this question cannot be answered in this paper, some indications suggest that waves of expansion and reduction of bank branch networks are indeed not only a concomitant with the shift from a centrally planned to a market economy but a phenomenon that can be observed in established market economies as well, though to a smaller extent and over a longer period of time.$^{81}$ Consequently, a recent study on banking in Europe came to the conclusion that neither the development of IT facilities nor the growing number of bank mergers have yet changed the important role of traditional bank branches for (retail) banking. ${ }^{82}$ This aspect has a lot to do with the great importance of face-to-face contacts for client acquisition, and the unique and dynamic character of places that is based on the activity of different actors.

81 Such indications are, for example, publications that investigate the impacts of the shift from periods of network expansion to massive network reduction in the UK and the US during the 1980s and 1990s (see LEYSHON and THRIFT 1995, 1997) or statistics about bank branch network development in different Western European countries (EU-15) (See EuRopäISCHE Kommission 1999): Between 1994 and 1997 the total number of commercial bank branches increased in Hungary by $8.6 \%$. In the EU-15 states the development was quite heterogeneous during the same period of time: in some countries, the total number of banking units continuously increased between 1994 and 1997 (e.g. Portugal: 24.7\%; Italy: 9.2\%). In France and Spain a turn in the network development occurred after 1995 when an expansion ended and a reduction began, while the opposite development took place in the Netherlands (assumed that not a formal change in statistics occurred: see below). Finally, a reduction of banking units proceeded in most countries (e.g. Denmark: -3.0\%; UK: $-11.8 \%$; Finland: -24.1\%). In Germany, the number of all banking units was reduced by $-6.9 \%$ between 1995 and 1997 (Author's calculation according to EUROPÄISCHE KOMMISSION 1999). The headline 'Less banks, more banking units' operating in Germany during the second half of the 1990s, published by the FAZ on January 18, 2000, is misleading, although it refers to the just quoted banking statistics. This is because these statistics include the branches of the German Postbank since 1995. (as part of the post offices they were existing before as well), but the dates of calculation were 1994 and 1997. Both categories of bank branches, i.e. Postbank branches and other banks' branches (1994-97: -3.7\%), were reduced in the second half of the 1990s (Author's calculation according to DEUTSCHE BUNDESBANK 1999).

82 EUROPÄISCHE KOMMISSION 1999, 21. 


\subsection{Geographies of Hungarian bank branch networks and alternative financial infrastructure in the $1990 \mathrm{~s}$}

In 1996, a branch network strategist, working in the headquarter of a middle-sized foreign-owned bank in Budapest, predicted that the strong competition for customers on the Hungarian banking market would be settled in $1999 .{ }^{83}$ Three years later, the situation was actually very different. Competition had grown even more in 1998 and 1999 when several banks opened up toward less contested segments of the market such as financing medium-sized companies or doing business with private individuals having medium to high income. Those banks who already dealt with such customers turned to sound customers in fields regarded as even more risky, including lending to households or small companies. This shift in lines of business was almost always accompanied by a change in the banks' branch network strategy. While a rather cautious network policy prevailed among banks founded with FDI in the first half of the 1990s, and even a reduction of branches took place among originally Hungarian-owned banks after their 'market euphoria' had ended in 1992, an accelerated expansion of branch networks occurred in almost all banks after 1995 .

In which way, if at all, has the location of the newly established or inherited branches mattered in this process? The argument is that analysing the spatial organisation of branches is necessary in order to achieve full understanding of banking in Hungary and the operation of different credit institutions. Thinking of the above described dialectic inherent in bank branches - i.e. expressing and encouraging regional development - it can also be expected to find some clues for reaching a better understanding of the regional transformation process.

\subsubsection{Inherited networks}

A common characteristic regarding the spatial organisation of the Hungarian banking system before and after the political transformation in 1990 has been an extremely high centralisation of headquarter functions in Budapest. ${ }^{84}$ In 1990, all headquarters of the banks were found in Budapest, while in 1999 only one bank, a state-owned regional development bank in Miskolc, had its headquarter outside Budapest. ${ }^{85}$ Three main reasons have been responsible for the centrally organised financial system in Hungary: ${ }^{86}$

- the historical dominance of Budapest within Hungary,

83 Interview conducted by the author in spring 1996.

84 For a detailed analysis of the regional distribution of jobs in Hungarian banking in 1980 and 1990, see JöNS (1996).

85 This specialised credit institution, the Rákóczi Bank, had started operation in 1992.

86 See JÖNS 1996, 75; JÖNS and KLAGGE 1997, 36. 
- the centrally managed socialist economy that made a concentration of decision-making necessary,

- the role of Budapest as the centre of innovation in the transformation process.

The only decentralised elements have always been the savings co-operatives. In addition to the savings co-operatives OTP maintained a nation wide branch network before 1990. The successor banks of the National Bank's banking department maintained branches outside Budapest as well, but, at the end of 1987, they maintained together less than a quarter of the branches operated by OTP at that time (97 versus 429). At this early stage of the re-established two-tier banking system, the smaller financial institutions, that were founded during the 1980s, had just started to build up their branch networks.

Between 1987 and 1990 the commercial banks' branch networks were enlarged by a considerable extent $(+28.4 \%)$. According to socialist principles of public supply, almost all regions and sizes of settlements benefited to a certain extent from the establishing of new bank branches in this period of time ${ }^{87}$ Nevertheless, the highest number of branches and lowest population-per-branch ratios ${ }^{88}$ continued to be concentrated in the major regional centres of the country that are more or less the large county capitals (figure 8). In the framework of the socialist regional development policy these major Hungarian towns had been decentralised development foci. They were situated along two 'rings of centrality' around $\mathrm{Bu}$ dapest. ${ }^{89}$ The distance between Budapest and the urban centres of the first 'ring' was about $100 \mathrm{~km}$, while those centres of the second 'ring' were located in about $200 \mathrm{~km}$ distance to Budapest. The country capitals in the eastern part of Hungary such as Miskolc, Nyíregyháza, Debrecen and Békéscsaba had been rather small urban centres in the less developed, agricultural part of pre-war Hungary, but in socialist times they became industrial centres through strong financial support by the government. At the end of the 1990s, the regional centres in the eastern part of Hungary equalled the other regional centres in many respects, not only in regard to the supply with banking infrastructure.

Hungary, like other socialist countries, had very low banking supply ratios. In 1990, slight west-east disparities existed that were preserved from pre-socialist times (figure 8). Pre-war disparities in banking infrastructure continued to exist in socialist times - though to a smaller extent - because the bank branch networks were mainly reduced when the one-tier banking system was created in 1947-50;

87 See JÖNS 1996.

88 The population-per-branch ratio is the inverse number of the branch-per-capita ratio. The first will be used in the figures of this article since the number of branches is quite low in comparison with the number of inhabitants, and thus this indicator is more vivid and better to handle. For a change, the term branch-per-capita ratio is used in the text as well. Both indicators facilitate the comparison to what extent a region or community is supplied with banking infrastructure.

89 For the origin of these 'rings of centrality', see JöNS 1996, chapter 3. 
they were not completely reorganised..$^{90}$ The lowest branch-per-capita ratios in the north-east of Hungary were also influenced by a higher population density in the northern counties and a lower urban density in eastern Hungary. ${ }^{91}$ Other disparities in the supply with banking infrastructure existed between different sizes of settlements. ${ }^{92}$ The smaller the settlements' size the lower was the branch-per-capita ratio. The small towns and villages had the most disadvantageous starting position regarding the shift towards the market economy. For people living in small settlements neighbouring bigger towns, the lack of a banking infrastructure was less problematic than for people living in less urbanised regions such as north-east Hungary or other rural areas throughout Hungary. ${ }^{93}$

Figure 8: The regional distribution of commercial bank branches in 1990

Source: See figure 1; population data from census 1990; author's compilation.

90 See ILLÉS 1994.

91 See JÖNS 1996.

92 The size of settlements is a very convenient analytical tool for examining the spatial organisation of bank branch networks in Hungary. This is because central planning was orientated to the settlements' population. In this hierarchical distribution system, the smaller villages were intentionally neglected (see, for example, Meusburger 1995, 143).

93 Compared with Austria in 1980, the ratio of employees in banking per capita was three times lower in Hungary than in the adjoining market economy. While the ratio of jobper-capita in banking reached 1:3 between Budapest and Vienna, this proportion reached 1:6 in the villages with less than 500 inhabitants (JöNS 1996, 60). 
However, one cannot 'blame' socialist policy for creating regional disparities in banking because banking had almost no significance for socialist society. It was only when the turn to market principles occurred that a different value was put on bank branches and thus regional disparities in the supply of banking infrastructure started to make a difference for several actors in society. The access to money and related matters suddenly became a social necessity, for money governs a capitalist market economy. Thus, local accessibility to credit institutions, the essential provider of finance for people and SME, represented a competitive advantage. This is what HAMILTON $(1995,1999)$ hypothesised as a 'commodification' process characteristic for the transition to a market economy. In his words, this process "radically alters the perception, value, functions and influence of space." According to HAMILTON $(1999,140)$, this re-evaluation of space affected natural and human capital resources as well as the location of a place.

\subsubsection{Developments in the urban hierarchy}

Until 1992 the former large state-owned banks established their new branches in all categories of settlements but the small villages with less than 5001 inhabitants (figure 9). Subsequently, they reduced their number of branches so that the level of 1990 was reached again in all categories of settlements at the end of 1994. Mainly the upper levels of the hierarchical urban system benefited from the second period of network extension among the former large state-owned banks (Budapest: $+30 \%$, big towns: $+16 \%$, middle-sized towns: $+11 \%) .{ }^{95}$ This shows that criteria typical for banks in market economies began to influence the branch network strategies of the former large state-owned banks only in the second half of the 1990s, often not until they were privatised ('foreignised').

The developments among the banks with FDI (except Postabank which will be analysed separately) suggest hierarchical top-down-diffusion par excellence: Starting with establishing the first branches in Budapest in 1990, the banks with FDI appeared in the middle-sized towns in 1991, in the small towns only after the period of strong network expansion had started (1995), and, finally, in the smallest villages in 1997. This top-down diffusion illustrates the character of drawingboard planning regarding the branch network strategies of banks with FDI. Since they originally aimed at acquiring sound customers in the most attractive segments of the market - multinationals, large joint-venture and Hungarian-owned companies - they consequently went to the largest agglomerations of potential customers first. Only when the competition got harder at the end of the 1990s did the banks deviate from their original strategy and spread out into smaller municipalities with less and different business opportunities.

94 HAMilton 1999, 140.

95 In the larger small towns (I) the expansion lasted only until 1996. It was followed by an even stronger reduction of branches (1994-98: -5\%). In the smaller small towns (II) nothing changed (in sum), and the small villages gained only $+9 \%$ until 1996. 
How important the regional perspective is in this respect, can be very well illustrated by the fact that the first appearance of banks with FDI in small towns in 1995 is not very spectacular since these towns - Piliscsaba, Pilisvörösvár and Törökbálint - are all located within the agglomeration of Budapest. They are suburban municipalities that already belong to the county Pest (figure 11). In contrast, the branches founded by banks with FDI in small villages from 1997 onwards deserve special attention. They are the first expression of the turn towards niche strategies among foreign-owned banks that was discussed in the previous section in detail and can be labelled as an opening towards so far neglected segments of the market: ${ }^{96}$ The first branch of interest is located in a village with only 3234 inhabitants (1998) in the north-east of Hungary. The niche is a strategic and profitable location along a major transport route to the Ukraine and Russia where special border needs (duty, money exchange etc.) for truck drivers and other travellers offer very promising business opportunities. The other innovative branch location is less unusual since Fertöd (3 079 inhabitants in 1998) is located near the border to Austria. The most important aspect of its location is, however, the fact that Fertöd is the home of the famous baroque castle of Esterházy, a major cultural and tourist attraction with international reputation.

From this observation it can be concluded that local knowledge became more important for banks with FDI at the end of the 1990s when the major centres were already 'occupied' by almost all banks. At this time, competition had not diminished (see above) but strengthened, and drawing-board planning was not sufficient anymore. Creativity, local knowledge and a certain amount of risk became the most important aspects for creating a competitive advantage through strategic branch network locations.

Among the large retail banks, Postabank, the second largest retail bank behind OTP, took the first initiative to strengthen local presence and thus to close the gap towards the network size of OTP. By opening 219 agencies in addition to its 40 fully-fledged branches in 1995, Postabank increased its presence in the middlesized and small towns considerably and thus created a competitive advantage before the contest for upper-level retail customers started. The fact that between one and three branches were closed in each of the six settlement categories before 1998 indicates that this extraordinary expansion of branch networks could not be sustained because the profitability of branch locations can only be experienced through business practice. Since the branch closures occurred in all sizes of settlements, the size itself seems to have little influence on the success or failure of a operative unit. The dynamic changes in the individuality of places seems to be responsible for this process (see below).

96 Actually, only two of the six branches of banks with FDI located in small villages in 1998 have been newly founded. The other two had been taken over from Mezőbank (by Erste Bank) and from MHB (by ABN-AMRO). 


\section{H. Jöns}

Figure 9: Branch network developments in the hierarchy of settlements, 1990-1998

Source: Author's compilation; see figure 1; population data from census 1990 and KSH 1998. 
In the small villages with 10 001-20 000 inhabitants the combination of a reduction of branches belonging to former Hungarian-owned banks (I), including the effects of institutional declining among medium-sized and small Hungarian-owned banks in the second half of the 1990s, and a relatively small number of new branches founded by banks with FDI (II) led to a rather insignificant increase of branches between 1994 and $1998(+6.5)$. The benefit of overall network expansion of commercial banks was also comparably low in the small villages $(+12.7 \%)$, while the other categories gained about a quarter of new branches in this period of time, and Budapest's branch networks even doubled (+49.7\%).

The population-per-branch ratio shows that the disparities between different sizes of settlements considerably decreased since 1990. In more or less all categories, the development of the ratio followed the familiar pattern of improvement until 1992, stagnation or deterioration until 1994, and another improvement until 1998. In 1998, the most favourable ratio was found in the middle-sized towns (5 427 inhabitants per branch), the big towns (5 982) and the larger small towns (6 012). The ratio of Budapest (6 960) is incomparable because of the high population density and short distances between branches, but the ratio in the small towns with less than 10000 inhabitants (8 540) already indicates a lack of supply of bank branches from the viewpoint of the population and SME. In the small villages the situation is much worse (51 501). The competitive disadvantage for actors in small villages and rural areas starts with the amount of time one needs to get to a branch and includes the access to information about profitable banking transaction or the clients' freedom of choice between competing banks. Although the minor role of commercial bank branches in the smaller villages is to a certain extent compensated by the activity of the savings co-operatives, the number of inhabitants per bank branch and savings co-operative was still three times higher in the small villages than in the middle-sized and small towns (ca. 5 000-5 800) in $1998 .^{97}$ Thus, disparities between rural and urban areas are among the most important disparities that can be observed in the geographies of banking in Hungary at the end of the 1990s. They hold the danger of 'financial exclusion, ${ }^{98}$ in the small villages of rural areas (see below).

97 The savings co-operatives are the most important provider of financial services in villages with less than 5001 inhabitants. Accordingly, the supply ratio for the small villages drops to 16291 inhabitants per banking unit when taking the co-operatives into consideration. This ratio would even drop more when the branches of co-operatives were included, but the ratio would still exceed those of the other settlement sizes. Unfortunately, the main source of data (KEREKES 1990 etc.) does not provide the possibility to assign the savings co-operatives' branches to the settlement where it is located, but at least it shows how many branches a certain co-operative has.

98 See LEYSHON and THRIFT 1995, 1997. 


\subsubsection{Regional transformation and its mediators}

The periods of branch network development outlined above are also connected with characteristic patterns regarding the choice of branch locations. Among the banks founded with FDI a diffusion can be traced from Budapest (1990) to the major regional centres $(1992,1994,1996)$ (figure 10). According to the branch network development all regional centres were equally attractive as branch locations for banks founded with FDI until 1996. As a result of socialist business policy, the urban centres along the two 'rings of centrality' were agglomerations of industrial companies. Although many of them were in a bad shape, there were still enough business opportunities for foreign-owned banks in all parts of the country. Accordingly, FDI in industry was concentrated in these regional centres, too. ${ }^{99}$

The two 'rings of centrality' are legacies from socialist times and represent the first factor that strongly influenced the banks' network strategies. Striving for presence in each county, about 15 to 20 locations, more or less corresponding to the number of county capitals, were initially attractive for banks with FDI. Drawing-board planning seemed to be enough for serving the rather élite clientele targeted in the first period of network construction until 1996. Thus, the main question for the banks at that time was not 'Where to go?', but 'Where to open first?'. Only when the competition had grown enormously did niche strategies become more and more important (see figures 10 and 11). The banks started to open branches

- in small towns located in the agglomeration of Budapest where plants and other subsidiaries of multinationals were to be found (1996, 1998: for example Schöller, Quelle and Lekkerland in Törökbálint or Tchibo and Family Frost in Budörs);

- in other smaller towns of Transdanubia, particularly in the north-west and the western border region (1998: for example in Fertőd and Keszthely because of tourism and heritage or in Pápa and Ajka because of industry);

- in selected municipalities in the rest of Hungary, 'even' including the eastern part (1999: for example in Barcs and Tuszér because of transport routes).

These niche strategies followed each other (not necessarily in one bank). When the one 'hazardous business' was not enough to get a competitive advantage, the next, more risky one was dared or when the best locations of the first strategy were already occupied, other banks looked for new profitable locations. The second and third strategies only developed after the banks decided to widen their clientele in the corporate sector and to get more involved in retail banking. To a certain extent this was necessary because in 1996 the banks founded with FDI were all found in the same locations along the rings of centrality (figure 11). Thus, changes in business strategy were not responsible for shifts in branch network strategies, but

99 See, for example, ASCHAUER 1995, 71. 
the regional organisation of the branch networks was a major cause of the shift in lines of business. This in turn produced changes of the network strategies. Therefore, the operation of the banking system and individual banks cannot be understood without taking account of the regional dimension.

The fact that drawing-board planning was not sufficient for successfully organising a branch network at the end of the 1990s leads to another conclusion related with the great significance of space for the operation of the Hungarian banking system and regional transformation. This refers to the bundle of criteria used by branch network strategists in order to decide 'Where to open a branch first?'. These criteria, named by branch network strategists of foreign-owned banks in 1996 and 1999, ${ }^{100}$ show how important the local context is for the opening of a bank branch:

- regional economic structure; indicators are, for example: number of exportorientated companies, especially from the banks' owners home countries; number of joint-ventures and all companies; real income or other social-economic indicators regarding the population;

- human capital resources;

- accessibility from Budapest in terms of the time to get there and a save communication line; ${ }^{101}$

- co-operation of local authorities;

- availability of an appropriate office building;

- competitive situation in regard to the activities of other banks.

With the emergence of niche strategies, these criteria were expanded and partly replaced by more sophisticated local particularities such as the location along major transport routes or important cultural and tourist centres. In any case, the conditions found at a certain place deserve special attention. For example, the availability of human capital resources is most important for finding a potential branch manager and thus for the opening of a new branch. The higher qualified a branch manager, the more independent from the headquarter (and regionally 'embedded') his decisions can be. Against this background, the fact that highly qualified people tend to leave small towns and underdeveloped regions in order to succeed in more prosperous regions has a considerable influence on the opening and operating of bank branches in these regions. That the role of local authorities should not be underestimated as well, can be illustrated by the statement of a

100 Interviews conducted by the author in different headquarters in Budapest.

101 In general, the opening of a bank branch is a rather time consuming process. On average one year before the actual opening takes place a bank manager from Budapest has to go to the respective place one to two times a week in order to do the necessary arrangements. Therefore, places which are not easy to reach have second priority. 
branch network strategists: "When they are not friendly, we go to another place. Why to fight if there is an easier way?"102

This leads to the following conclusion: First, small and middle-sized banks founded with FDI could not come to Hungary and exclusively rely on standardised criteria for network development. Since the end of the 1990s, they have to pay close attention to the regional and local contexts in order get a better chance to succeed in the current stage of banking competition. This close attention is necessary in order to save costs in network development. Nevertheless, the profitability of a branch is never completely predictable because of the dynamic changes in the individuality of places. Secondly, it is the activity and availability of local decision-makers and actors that can influence the opening of a bank branch considerably. After the branch has opened, it is a local actor itself and therefore also contributes to the role of the respective place or administrative unit within the changing urban hierarchy and regional structure of Hungary.

Although the individuality of places and the relation between places are constantly changing, ${ }^{103}$ these dynamics are especially high during political-economic transformation. The break up of the rigid hierarchy between different sizes of settlements characterising the regional structure of the centrally planned economy in Hungary, means a complete revision of the interrelation between places. In this process of shaping new identities of places, the mediating role of local human and nonhuman actors (actants) ${ }^{104}$ can be regarded as another decisive factor besides the earlier identified influence of legacies from socialist times. In the case of bank branch network development these mediations include the commitment of the mayor, the availability of a convenient office building, the 'co-operation' of a communication line, the mobility of highly skilled people, industrial investments, the bankers' decisions and more.

Considering the branch network development of banks with FDI in 1998 and 1999 again (figures 10 and 11) the preference for the north-west of Hungary is most striking. This is best explained by the prevailing contact patterns and potentials for interaction that almost reversed for Hungary after the political transformation towards the market economy. ${ }^{105}$ In socialist times, the country was focused on economic collaboration with Russia and the other CCE countries. Funds were centrally gathered and transferred to the east, especially the north-east. As banking was not significant for the economy, these contact patterns did not manifest themselves in banking, but in industrial sites (for example in Borsod-Abauj-Zemplén).

102 Interview conducted in the headquarter of a foreign-owned bank in spring 1996.

103 See, for example, MASSEY 1984.

104 These terms are used according to actor-network theory (see, for example, LATOUR 1999). Based on a understanding of agency as the capacity to have effects, actor-network theory restores agency to things. Since the term actor in other contexts tends to be limited to humans, the term actants is used in order to refer to humans and nonhumans (objects, things) at the same time.

105 See, for example, HAMILTON 1995, 74 
Figure 10: Bank branches opened by commercial banks founded with FDI (left side) and bank branches closed by all commercial banks (right side), 1990-1998

Source: Author's compilation; see figure 1 . 
With the turn towards the market economy and the wish to become a EU member state the new potential collaborators were found in Western Europe. Several foreign companies founded or took over plants in the western part of Hungary in order to use economic advantages in Hungary (salaries, taxes etc.) and short ways to the Western European market (for example in Györ-Sopron). ${ }^{106}$ Thus, changing contact patterns and potentials for interaction make up the third aspect that strongly determines regional transformation of Hungarian banking.

Thinking of the foreign-owned banks' criteria for the opening of bank branches again, it becomes obvious that there are actually a few potential profitable branch locations outside the regional centres in the east, too, but these have been neglected by the banks so far (examples are Tokaj or Gyula). In general, interviewees stressed the comparably cost-saving procedure of opening branches in the eastern part of Hungary because of lower prices for real estate or lower salaries. Nevertheless, it seems that apart from economic disparities the prevalent discourse about the 'depressed' and 'peripheral' east makes the banks even more hesitant to open branches in locations other than the regional centres of eastern Hungary.

This is not the only way that ideas about different regions in Hungary influence the regional strategies of banks founded with FDI: JÖNS (1996) and JÖNS and KLAGGE (1997) pointed out that the branches of banks founded with FDI were found in all regional centres in 1996, but that they had different functions. Branches in the eastern county capitals concentrated on mobilising savings, while credit allocation was very restrictive in the eastern part of the country. Consequently, the banks transferred collected deposits via the headquarter in Budapest to branches in the Budapest agglomeration and northern Transdanubia in order to allocate credits to almost all kinds of companies. Assuming that two entrepreneurs, one located in Debrecen and the other in Györ, ask for credit in order to build up the same business that does not depend so much on a strategic location, the one in Györ would have a much greater chance to get this credit because the real differences in economic development are often passed on to the success of the respective business project, even if they would not matter much in these cases. As a result, the person in Debrecen would probably become mobile and move, for example, to Székesfehérvár in order to realise his project.

Thus, banks founded with FDI contributed to the deepening of uneven regional development in a twofold way: first, with opening those branches, which are founded outside the regional centres, mainly in small towns located in western Hungary, and secondly, with the division of labour just described - and generalised - between branches in different regions of Hungary. It is argued here that geographical imaginations reinforce real differences in economic development

106 Examples are companies located in the agglomeration of Budapest such as those mentioned before or Opel in Szombathely or Philips in Veszprém. 
which in turn are responsible for both strategies. These results support John Agnew's argument that "people in the world use regional designations to make sense of the world and these draw on real differences between parts of the world but they cannot claim total fit to the world because they are based on ideas about regional differences that are not simply about those differences per se but also about ideas of how the world works." 107

Finally, looking at the branch networks of the major retail banks with mediumsized and large networks that are not included in figure 11 (OTP, Postabank, $\mathrm{K} \& \mathrm{H}, \mathrm{ABN}-\mathrm{AMRO}$ Bank, Budapest Bank, Erste Bank), two more ways in which regional transformation has been mediated can be identified (figure 14): First, another contribution of legacy is expressed by the branch network of OTP that was inherited from socialist times. This is because there are still more branch locations occupied by commercial banks outside the regional centres in the eastern part of Hungary than would be expected from the behaviour of the banks founded with FDI. Nevertheless, OTP and other retail banks recently also started to encourage a deepening of the west-east disparities in access to banking by closing branches primarily in the eastern part of the country (figure 10). Other influences of legacy, even from pre-socialist times, are high population densities in the northern counties and lower urban densities in the eastern counties that add to the lower branch per population ratios in the eastern part of Hungary. Secondly, the influence of the banks' agency on regional transformation is expressed once more in the spatial specialisation of branches. ${ }^{108}$ In the large bank branch networks in Hungary, the highest responsibility outside Budapest is centralised in four to eight regional directorates. With the decision to declare a branch location as regional directorate, the banks contribute to a further differentiation between the function of towns along the rings of centrality as regional centres. Other banks are mostly operating full-service branches and (specialised) sub-branches. ${ }^{109}$ The hierarchy between branch locations within individual branch networks has been constantly changing during the 1990s in almost all banks because of ongoing changes in the individuality of places and their interrelations. In the long term, new sets of (still changing) relations that are different to socialist times will characterise the position and functional 'identity' of each place in the regional and urban hierarchy of the Hungarian market economy.

Thus, legacies, agency of several kinds of human and nonhuman actors, contact patterns and potentials for interaction as well as ideas about regional differences have been identified as determinants for uneven regional development in Hun-

107 AGNEw 1999, 93. For the implications of this argumentation in regard to its critique of both realist and constructivist approaches, see AGNEW (1999).

108 The spatial specialisation of bank branches is described by LEYSHON and THRIFT (1997, 217) as one of the major aspects of corporate restructuring in the UK during the 1990s.

109 Postabank is an example for a four-tier system with regional directorates, full-service branches, agencies and post offices as external service units. 
garian banking during the transformation process towards a market economy. Considering also the periods of network development identified before, the empirical investigations contributed to a better understanding of the opening and closing of branches (figure 10) as well as the distribution of commercial banking infrastructure in 1998 that can be regarded as the result of all kinds of network activity by commercial banks (figure 12). The most striking aspect of the spatial organisation of Hungarian bank branch networks in 1998 is the distinct west-east disparity regarding the population-per-branch ratio: The regional structure of Hungarian commercial banking was somehow polarised around the centre of $\mathrm{Bu}-$ dapest (6 960) between Györ-Sopron, Vas, Zala and Somogy (ca. 6700 to 7 300) along the western border region to Austria, Slovenia and Croatia on the one hand, and Borsod-Abáuj-Zemplén, Szabolcs-Szatmár and Hajdú-Bihar (ca. 10 600- 11 700) in the north-east of Hungary, along the border to Slovakia, Ukraine and Romania, on the other hand. Nevertheless, the disparities between the different counties lowered between 1990 and 1998 because of the change in meaning of banking for society and the role of legacies that made all regions benefit from new branches. The change in meaning of banking for society resulted as much as the 'commodification' process described by HAMILTON (1999) and the earlier described mind-sets from the major change in ideology that became manifest in 1989/90. The investigations of this section have shown that all the different expressions of a comprehensive, ideology-based 're-evaluation of space' were very influential on the regional transformation of Hungarian banking.

Figure 12: Bank branches (1998) and population-per-branch ratios (1990-98)

Source: See figures 1 and 9; author's compilation. 


\subsubsection{Alternative financial infrastructure and 'financial exclusion'}

Comparing the total ratio of inhabitants per banking units in Hungary 1997 227; including all types of credit institutions and branches of co-operatives) with the same ratio in market economies of Western Europe shows that Hungary has reached the level of network density in the EU countries after the first decade of transformation. In 1997, Hungary held a position below average within very heterogeneous ratios among the EU countries. ${ }^{110}$ This fact underlines once more the importance of branches for the operation of Hungarian banks during the 1990s. Nevertheless, the geographies of banking showed an relatively high concentration of commercial bank branches on Budapest and the county capitals (figures 9 and 14). Only $13 \%$ of the 3131 Hungarian municipalities (1998) had at least one bank branch or main office of a savings co-operative (figure 14). In some of the other $87 \%$ of municipalities branches of savings co-operatives or alternative financial infrastructure such as post offices and ATMs might have been available, but, however, figure 14 shows that there were immense regional disparities regarding the accessibility of banking units, the supply of high-quality services, and the opportunity to choose between different competing banks. The banking dilemma for people in rural areas can be illustrated by the fact that peasants have no chance to get credit from banks (land has only a low value), while the amount of money necessary for a new tractor or other investments often exceeds the credit limit of local savings co-operatives.

Although the ATM network was extended considerably between 1997-1999, it did not help to improve access to banking everywhere. The distribution of ATMs in 1999 showed once more distinct west-east disparities and an immense concentration in the regional centres, especially in the eastern counties (figure 13). In this respect, the card-accepting banking units were much more widespread due to the decentralised networks of the savings co-operatives that were operating about $60 \%$ of the Hungarian banking units in 1998. However, the availability of decentralised banking services does not guarantee the use of them. ${ }^{111}$ First, people have to gain knowledge of it, secondly, they need to develop trust in banking transactions, ${ }^{112}$ and thirdly, they have to get access to the respective services. While the first two aspects can only be achieved through face-to-face contacts, the latter requires a minimum amount of income or own funds. Thus, IT can only serve as a supple-

110 The ratio of Hungary was similar to those in the UK (3 681), in Sweden (3 514) and Finland (3 101) (Author's calculation according to EurOPÄISCHE KOMMISSION 1999, and recent population statistics from the respective national statistics offices).

111 For example, 25 banks and 144 savings co-operatives issued bankcards at the end of 1998, but the number of cards reached only 2.9 million (NATIONAL BANK OF HUNGARY 1999a, 14). This resembles less than one third of Hungary's population or the number of inhabitants in the nine largest Hungarian towns.

112 Gaining trust in banking is one of the major tasks for people of the emerging market economy of Hungary (see page 23). For the general relation of virtual money and trust, see LEYSHON and THRIFT 1997, 30. 
mentary service at this stage of the transformation process in Hungary. Neither for the customers nor for the banks' acquisition of clients can IT replace the traditional bank branch in the medium range, but, however, it will become a competitive advantage for banks in the long-term perspective. ${ }^{113}$

Figure 13: Distribution of ATMs and card-accepting bank branches, 1999

Source: NATIONAL BANK OF HUNGARY 1999c; see also figures 1 and 9; author's compilation.

Taking into consideration that retail services, in general, are still not as developed as in Western European countries, and that the market share of savings cooperatives was only $5 \%$ altogether $(10-15 \%$ were reached in some products of the household business branch), ${ }^{114}$ the danger of a two-tier banking community becomes quite obvious: one represented by predominately foreign-owned banks, offering sophisticated services for large and medium-sized companies as well as people of the higher social strata; the other consisting of Hungarian-owned cooperative credit institutions with rather low capitalisation, offering mainly basic

113 Since a demand for sophisticated banking services already exists among companies and people of the higher income strata, the banks introduced and substantially extended phone and home banking services, ATMs, small banking units and electronic branches in shopping centres at the end of the 1990s (NATIONAL BANK OF HUNGARY 1999a, 15).

114 SzÖKE 1998, 587. 
banking services to the public: ${ }^{115}$ "There are still no signs of banks, which intend to increase their shares in the retail market, wishing to open up towards lowerincome strata. [...] In addition to the upper middle class, banks would prefer to see strata still belonging to the middle class having lower but regular incomes, among their clients." 116

In Hungary, there is a danger of 'financial exclusion'117 in many small towns, small villages and rural areas, especially in the eastern part of the country but also in parts of Transdanubia. Furthermore, there is a great inequality in access to banking within towns or communities between people with none or low income and those with at least medium income (especially, because local co-operative credit institutions are missing in bigger towns, and the banks are concentrating on people with medium and high income). According to LEYSHON and THRIFT (1995), financial exclusion could be countered by promoting "alternative financial infrastructure which can, in particular, supply the basic banking facilities and lowcost loans to low-income households." 118 For Hungary, this means in the first place a strengthening of co-operative credit institutions as the most important provider of finance in rural areas. That the sector of co-operative credit institutions is not only underdeveloped in regard to capitalisation can be illustrated by two more facts: first, there were much more co-operative credit institutions working in Hungary before World War II than today; ${ }^{119}$ secondly, the Hungarian supply ratio regarding commercial banks ( 8858 inhabitants per branch) was even better than the same ratio of Germany in 1997 (9 931), while the respective ratio regarding co-operative credit institutions was more than twice as high in Hungary (5 077 versus 2130 in Germany). ${ }^{120}$

Some other strategies for avoiding further economic and social marginalisation of people in places threatened by 'financial exclusion' were already implemented by the government; on the one hand by founding a regional development bank in Miskolc, and on the other hand by introducing different project-related state funds through the Hungarian Development Bank and the Eximbank. ${ }^{121}$ The breaking up of prejudiced ideas about the eastern part of Hungary 'as a whole', and trying to keep motivated people in the region and to support their activities could be helpful for lessening the deepening of uneven regional development, too.

115 The metaphor of the two-tier economy was adopted from JONES (1999) who applied it to the whole Hungarian economy.

116 NATIONAL BANK OF Hungary (1999a, 14).

117 LEYSHON and THRIFT $(1995,341)$ defined this term as "processes that prevent poor and disadvantaged social groups from gaining access to the financial system."

118 LEYSHON and THRIFT 1995, 336. Examples for this infrastructure are post offices, community development banks, credit unions or non-financial retail outlets.

119 ILLÉS 1994, 168.

120 Author's compilation according to DEUTSCHE BundESBANK (1999).

121 See JÖNS 1996. The constructions of both state-owned banks are available in almost all commercial banks and savings co-operatives. 
For the next decade, two main developments for the spatial organisation of Hungarian banking (and thus the operation of the banking sector) can be expected:

- the founding of foreign bank branches as independent institutions with a preference for branch locations in the western border region, ${ }^{122}$

- a period of network stagnation and reduction after the tough competition is over; these prospects emphasise the important role of co-operative credit institutions and thus local initiatives for future banking in Hungary.

\section{Conclusion and regional transformation theory}

Examining the development of the Hungarian banking system between 1987 and 1999 reveals a bundle of complex interrelated dynamic changes regarding legislation, institutions and the banks' business and branch network strategies. Thus, the first result is a comprehensive periodisation of different developments related with Hungarian banking in the first decade of political-economic shift from a centrally planned towards a Western European style capitalist market economy (figure 15). Compared with preceding decades, Hungarian banking experienced extraordinary instabilities in time and space during this period. The main reason for this instability was the major ideological change that became manifest in 1989/90. This transformed the meaning of banking within Hungarian society. In some respects, the preliminary 'results' of these major changes seem very often to be comparable with the state of affairs at the 'starting point', although the qualities of the respective state of affairs are completely different (figure 15).

The second result is that one cannot understand Hungarian banking in the 1990s without examining the spatial organisation of branch networks as well as the significance of the individuality of place for the opening, operating and closing of banking units. The basic principle of this finding was already pointed out by MASSEY (1984) in regard to the spatial organisation of production: "It is not, then, just a question of mapping social relations (economic, sociological or whatever) on to space. The fact that these relations occur over space matters. It is not just that 'space is socially constructed' [...] but that social processes are conducted over space." ${ }^{, 23}$ Furthermore, understanding local particularities and their interrelations within capitalist production is central for the new regional geography outlined by MASSEY (1984). LEYSHON and THRIFT $(1997,189)$ pointed in a similar direction when they stated in regard to banking that "each monetary network takes up space

\footnotetext{
122 The founding of branches by foreign banks without having a subsidiary bank in Hungary was allowed in 1998, but it has not happened yet. It can be expected to happen when the legal status of these branches will have to be harmonised with EU standards (right now, they are basically handled like subsidiaries) (NATIONAL BANK OF HUNGARY 1999b, 93).

123 MASSEY 1984, 56
} 
and space is constitutive of each network." The essential interdependencies between space, place and banking in Hungary during the 1990s, which came to light in this article, can be summed up as follows:

Figure 15: Transformation in time and space: the case of Hungarian banking

Source: Author's design.

- The major shift in the business strategies of several commercial banks at the end of the 1990s, which meant an opening towards so far less attractive segments of the market, did not simply lead to different branch network strategies. They resulted from the interrelation of an increasing number of commercial banks, growing competition, and the spatial organisation of branch 
networks at that time. In 1996-97, the competing banks found themselves all seeking for the same customers in the same places. One way of looking for new business opportunities was to go to other places, and thus they had to suit the business activities to the spatially less concentrated customers.

- At the current stage of transformation, marked by high competition, most commercial banks have to branch out in other places than those that are most likely profitable branch locations in order to get a competitive advantage for acquiring new clients. Thus, creativity, local knowledge and a higher amount of risk replaced drawing-board planning as main branch network strategy for most Hungarian banks at the dawn of the $21^{\text {st }}$ century.

- The bank branch network development is characterised by waves of network expansion and reduction. These dynamics depend on the banks' ongoing conflict between cost reduction and client acquisition, and the dynamic individuality of place. The latter is characterised by constantly changing relations of different actors (actants) and makes the profitability of a branch location not completely predictable. Banks have to try out through business practice whether or not a place is profitable enough to maintain a branch. Thus, bank branch network development can to a certain extent be regarded as a process of trial and error. These dynamics, which are probably characteristic for banking in market economies, seem to be exceptionally high during a period of political-economic transformation such as the one monitored in Hungary because interrelations between places are completely reorganised.

- Traditional bank branches are indispensable for client acquisition in current political-economic transformation in Hungary. People have to learn to cope with the principles of the market, including the opportunities, function, value and limits of banking transactions, and this can only be achieved by establishing branches as places of face-to-face contacts. Currently, IT serves as an additional intermediary, but it will gain growing importance in the future.

- In the first decade after the political transformation in Hungary, commercial banks founded with FDI contributed to a deepening of uneven regional development in a twofold way: first, with opening those branches, which are founded outside the regional centres, mainly in small towns located in western Hungary, and secondly, with a spatial specialisation of branches in different regions of Hungary. Thus, there is a danger of 'financial exclusion' in many small towns, small villages and rural areas of Hungary, especially in the eastern part of the country. Furthermore, there is a great inequality in access to banking within towns or communities between people with none or low income and those with at least medium income.

- The ongoing branch network expansion among commercial banks at the end of the 1990s is forced by tough competition for clients. Currently, banks are dependent on people and enterprises as potential customers. A period of network reduction can be expected when the run on clients will be decided, competition will have slightly decreased, people will have got acquainted with 
banking transactions and related business opportunities, and banks have tried out the value of different branch locations. Then, people will be dependent on the access to banking infrastructure, so that a reduction of costly branches can be 'dared' from the banks' views. In view of these prospects and current processes that can be characterised as 'financial exclusion', the strengthening of the underdeveloped co-operative banking sector should be an important task in Hungary for the near future.

In order to understand these processes theoretically, a combination of MASSEY's $(1999,28)$ understanding of space as 'a product of interrelations', as 'the sphere of the possibility of the existence of multiplicity' and as being 'always in a process of becoming', and the concept of actor-network theory as outlined by Bruno LATOUR (1999) and others can be very helpful. ${ }^{124}$ Since the latter regards the world as a complex web of strongly connected human and nonhuman actors that are constantly involved in network building processes, regional transformation can be understood as the result of a collective of place-specific actor-networks that are continuously changing through events under the influence of either a few or complex bundles of mediators. From this perspective, sets of complex associations between the different mediators are responsible for the interlinking of places.

As mentioned above, the interrelations between mediators and thus between places were completely rearranged in Hungary during the 1990s because of the change in ideology and the new role of banking. Which mediators, or - in terms of actor-network theory - 'actants', were responsible for regional transformation of Hungarian banking during the 1990s and thus for the deepening of west-east disparities in banking infrastructure is revealed in this article (figure 16). The most important were such heterogeneous aspects as the agglomeration of potential customers, the degree of population densities, legacies of socialist and also presocialist times, contact patterns and potentials for interaction, appropriate legislation, the commitment of the mayor and other decision-makers of local authorities, the availability of a convenient office building, the co-operation of a save communication line, the accessibility of a branch location from Budapest, the availability and mobility of highly skilled people or the presence of competing banks. Also responsible in the complex web of mediators were geographical imaginations about Hungary in which existing differences in regional development were reinforced by potentials for economic interaction and an ideology-based differentiation and evaluation of recent and former contact patterns. These geographical imaginations resulted from a re-evaluation of space under the influence of marketorientated criteria and the political-economic orientation towards EU countries. ${ }^{125}$ As one of their effects, they supported the banks' hesitation to open new branches

\footnotetext{
${ }^{124}$ For the application of actor-network theory to geographies of finance in other contexts, see THRIFT 1996 and LEYSHON 1997.

125 See Hamilton 1999.
} 
in other locations than the regional centres of eastern Hungary, as well as the introduction of regionally specialised branches. At the same time, legacies regarding contacts and potentials for interaction with the adjoining eastern countries (Russia, Ukraine, Romania) have been underestimated. It can also be assumed that the melange of facts and fictions contributed to migration from the eastern regions to Budapest or 'the west' which in turn led to a lack of human capital resources in economically less attractive regions. In this way, important links within place-specific actor-networks were eliminated. Links that would be necessary for the banks' decision to open a bank branch there. Thus, the mediations of human actors, institutional actors, nonhuman actors as constituted, for example, by legacies or local infrastructure, contact patterns, potentials for interaction and geographical imaginations were mingled in the process of regional transformation of Hungarian banking during the 1990s (figure 16). For each bank branch it would be possible to follow a chain of associations between the specific actants or mediators that are responsible for its existence. One missing or disappearing link could already prevent the establishment of a new branch or force the closure of an existing branch.

However, granting ideas a capacity to have effects would mean that according to actor-network theory they are actants themselves, but the fact that actor-network theory only distinguishes between human and nonhuman actors already indicates that this would have broad implications. Without referring to actor-network theory, AGNEW (1999) suggested that "[r]egions both reflect differences in the world and ideas about differences." 126 While he discusses general philosophical consequences of this concept, ${ }^{127}$ which was supported by the findings of this study, the implications of granting ideas the capacity to act for actor-network theory are to be exemplified in the following in order to apply the resulting concept to regional transformation theory: The main argument is that actor network theorists have failed to consistently disentangle all types of mediators that are responsible for network building processes since they left out ideas in the concept of humans and nonhumans. According to actor-network theory, ${ }^{128}$ the involvement of nonhuman actors in human interaction and the exchange of properties between human and nonhuman actors enables the stabilisation of social relations and thus the formation of the collective we are living in. ${ }^{129}$ This argument leads to the theory's 'symmetrical principle' between human actors on the one side and nonhuman actors on the other side with both kinds of (hybrid) actors having the potential to act (figure 17a). ${ }^{130}$ However, in the final analysis this conceptual symmetry of

126 AGNEW 1999, 93.

127 The main philosophical consequence of conceptualising regions this way is a critic of both realist and constructivist approaches (see AGNEW 1999).

128 The technical terms such as 'actants', 'human actors', 'nonhuman actors', 'collective', 'historicity' and 'hybrid' are used according to actor-network theory (LATOUR 1999).

129 See Latour 1999, 198.

130 See, for example, LATOuR 1999, 182; MuRdOCH 1997, 331. 
actor-network theory is not consistent since what is referred to as humans in actornetwork theory means much more than what counts as nonhumans: On the one hand, nonhumans (also named quasi-objects, inscriptions or immutable mobiles) seem always to belong, at least partly, to the material world. ${ }^{131}$ On the other hand, humans show all the attributes of nonhumans as well, especially the (socio)materiality that is vividly expressed in the human body, but they are also able to deal with ideas that can be regarded as immaterial pendant to nonhumans. It can be argued that disentangling what is happening on the side of human beings would be necessary for achieving full understanding of network building processes (such as involved in regional transformation), and that the complex attributes and skills associated with humans such as body, brain, mind, spirit, language, knowledge or culture facilitate competencies that are always superior to those of nonhumans. As a result, much more is happening on the side of the humans, and their mediation appears to be indispensable for "socializing nonhumans to bear upon the human collective." 132 What follows from this is an unequally distributed power-balance between human and nonhuman actors, and thus an asymmetrical relationship (figure 17b).

Nevertheless, it seems to be possible to establish a real conceptual symmetry within actor-network theory taking into consideration the mediating role of what I called 'suprahuman actors' in figure 16: individual experiences, stereotypes, mindsets, language and all kinds of other stored information, ideas, images and thoughts that strongly influence human agency and thus are actants themselves. This introduction of 'suprahuman actors' establishes a consistent symmetrical principle centred around the most hybrid and dynamic entities known so far, i.e. human beings (figure 17c). Understanding human actors as being entities in which suprahumans and nonhumans are tied together in a very dynamic way ${ }^{133}$ and that actively tie together other actants, it becomes obvious that their competencies, because of the combinational power, are ultimately greater than those of singular suprahumans or nonhumans. Nevertheless it is important to stress that within the suggested concept all three types of actants still have the same responsibility for action, and can all be hybrids in regard to their historicity. ${ }^{134}$

Figure 16: Understanding regional transformation from the perspective of banking

131 See, for example, LATOUR 1993, 79, 138.

132 LATOUR 1999, 296.

133 There are, for example, no inherited or 'new' human actors thinkable (figure 16); humans just have more links with either inherited or new non- and/or suprahumans.

134 This argument is crucial because it strongly supports the most important achievements of actor-network theory. For actants' responsibility for action, see LATOUR 1999, 183. The notions of sociomaterial hybridity and the historicity of things are developed in LATOUR 1999, chapters 5 and 6, see especially 212-214. 
56 H. Jöns

Source: Author's design.

Figure 17: Extending actor-network theory by introducing a third type of actant and a different understanding of humans 
Source: Author's design.

Thus, applying actor-network theory to regional transformation in Hungarian banking reveals two major inconsistencies in the theory. First, there is a misinterpretation of the role of humans (and certain nonhumans) due to an insufficient concept of hybridity; and secondly, there is a suppression of the immaterial counterpoint to (socio)material nonhumans. My main argument is therefore that interactions cannot only be stabilised and extended through time and space by the use of matter, but through the involvement of memory, too. The contribution of what I called 'suprahuman actors' to interaction in general or regional transformation in particular can be as important as that of nonhuman and human actors. Nevertheless, the involvement of human actors is indispensable for forming actor-networks such as bank branch networks. Only in this sense, do humans differ from the other actants. ${ }^{135}$

In 2000, the mediation of human, nonhuman and suprahuman actors resulted in a rather polarised regional structure of Hungary between the north-west and the north-east with Budapest as the dominant centre in the middle. Actually, the new

135 For the full background and implications of this reformulation of actor-network theory, see JöNS (forthcoming). 
sets of relations between the millions of unique places or 3131 administrative units in Hungary are much more complex, of course. They are constantly shaped in the - endless but becoming less dynamic - 'construction' of a new urban hierarchy and regional structure of the emerging market economy of Hungary. This construction is the expression of the sum of actions performed by human, nonhuman and suprahuman actors. Influencing the mind-sets about the eastern part of Hungary by stressing positive aspects of this regions such as future potentials of interaction along the eastern border region could be one way of contributing to a better business environment and more bank branches outside the regional centres in this region.

Some of the phenomena identified in this article as decisive for uneven regional development in Hungarian banking during the transformation process towards a market economy, have been addressed in the context of transformation by other authors as well. ${ }^{136}$ Nevertheless, the relation of these factors are hardly discussed, and the active participation of mind-sets seems to be underestimated. Prevalent ideas about the eastern part of Hungary seem to reinforce existing differences in 'place-specific factor endowments ${ }^{137}$ considerably. The value of the proposed concept of human, nonhuman and suprahuman actors presented in figures 16 and 17 can be illustrated by the fact that the "key factors in uneven regional development of post-socialist Europe," summed up by DingSDale $(1999,148)$, can be 'reduced' or 'abstracted' to the mediation of these three types of actants [main responsibilities are indicated in brackets]:

- western capital and ideas imported through direct foreign investment; [humans, suprahumans and relations, especially mind-sets and potentials for interaction]

- corporate location strategy; [humans, nonhuman legacies and suprahumans]

- sectoral and enterprise restructuring; [humans, nonhuman legacies and suprahumans]

- the slowness of governments to formulate regulatory policy and regional policy; [human actors]

- the local impact of indigenous private and public entrepreneurship; [human actors]

- deterrence of environmental legacy; [nonhuman legacies and suprahumans, i.e. action takes place somewhere else $]^{138}$

136 See, for example, HAmiLton 1999. The role of legacy from pre-socialist and socialist times is among the best explored phenomena in regional transformation theory (see, for example, FABMANN 1999, 16; HAMILTON 1999, 140).

137 This term is used by HAMILTON $(1999,140)$.

138 Deterrent industrial sites were found in all parts of Hungary at the end of the 1980s. It can be suspected that the suprahuman 'results' of the re-evaluation of space such as the discourse about the 'depressed' East, and the new contact patterns made a difference in the quality of deterrence in different parts of the country. 
- $\quad$ tourism and transport; [nonhuman legacies, new nonhumans, human actors]

- economically motivated cross border co-operation. [suprahuman legacies, new suprahumans, human actors]

Thus, the empirical findings of this article seem to fit into existing reflections on regional transformation theory, if somewhat slightly modifying and reorganising them. Furthermore, these investigations seem to have revealed and dissolved an asymmetry implicit in actor-network theory. The introduction of 'suprahuman actors' established a consistent concept of actants centred around human beings as the most hybrid and dynamic entities known so far. The author suspects that the actants identified as decisive for understanding regional transformation of banking could be valuable for understanding other aspects of regional transformation as well. The best way to check this assumption would be further research into regional transformation of banking in other post-socialist countries or of other social dimensions in Hungary that is based on the proposed concept of actants.

\section{References}

Agnew, J. (1999): Regions on the Mind does not Equal Regions of the Mind. Progress in Human Geography 23 (1), 91-96

ASCHAUER, W. (1995): Bedeutung und regionale Verteilung von Joint-Ventures in Ungarn. In: Meusburger, P., Klinger, A. (eds): Vom Plan zum Markt: Eine Untersuchung am Beispiel Ungarns. Heidelberg

BALASSA, Á. (1996): Restructuring and Recent Situation of the Hungarian Banking Sector. Budapest (= NBH Workshop Studies 4)

BognÁr, K., ForgÁCS, A. (1994): National Bank of Hungary: 70 Years of Existence (1924-1994). Budapest

Botos, K. (1998): The Status and Prospects of the Hungarian Banking System. In: Vorst, K. S., WehMEYER, W. (eds): Financial Market Restructuring in Selected Central European Countries. Aldershot, 83-101

BuCH, C. M. (1997): Opening Up for Foreign Banks: How Central and Eastern Europe Can Benefit. Economics of Transition 5 (2), 339-366

Busch, U., WeISIGK, D. (1997): Das Engagement ausländischer Geschäftsbanken in Ungarn. Bank-Archiv (11), 901-910

Cséfalvay, Z. (1994): The Regional Differentiation of the Hungarian Economy in Transition. GeoJournal 32 (4), 351-361

Deutsche BundesbanK (ed.) (1999): Bankenstatistik Dezember 1999. Wiesbaden (= Statistisches Beiheft zum Monatsbericht 1)

Dingsdale, A. (1999): New Geographies of Post-Socialist Europe. The Geographical Journal 165 (2), 145-153

ERDEI, T. (1998): Circumstances and Prospects. In: KeREKES, G. (ed.): Hungarian Financial and Stock Exchange Almanac 1997-1998. Budapest, 117-119 
EUROPÄISCHE KOMMISSION (ed.) (1999): Banken in Europa: Daten 1994-1997. Luxemburg (Panorama der Europäischen Union)

FAßMANN, H. (1999): Regionale Transformationsforschung: Konzeptionen und empirische Befunde. In: Pütz, R. (ed.): Ostmitteleuropa im Umbruch: Wirtschafts- und sozialgeographische Aspekte der Transformation. Mainz (= Mainzer Kontaktstudium Geographie 5), 11-20

Hamilton, F. E. I. (1995): Re-evaluating Space: Locational Change and Adjustment in Eastern and Central Europe. Geographische Zeitschrift 82 (2), 67-86

Hamilton, F. E. I. (1999): Transformation and Space in Central and Eastern Europe. The Geographical Journal 165 (2), 135-144

Hungarian BANKING AND CAPITAL MARKET SuPERVISION (ed.) (1998): Annual Report 1997. Budapest

ILLÉS, I. (1994): The Banking System and Regional Development in Hungary. In: Hajdú, Z., HoRváth, G. (eds): European Challenges and Hungarian Responses in Regional Policy. Pécs, 167-171

JONES, C. (1999): Foreign Affairs. The Banker 149 (881), 41-43

JÖNS, H. (1996): Bankwesen und Regionalstruktur beim Übergang von der Planzur Marktwirtschaft in Ungarn: Eine wirtschaftsgeographische Analyse der Transformation des ungarischen Bankwesens zwischen 1980 und 1996. Heidelberg (Diplomarbeit, unpublished)

JÖNS, H. (forthcoming): Räumliche Mobilität und grenzüberschreitende Kooperation in den Wissenschaften: Deutschlandaufenthalte US-amerikanischer Humboldt-Forschungspreisträger aus einer erweiterten Akteursnetzwerkperspektive. Heidelberg

JÖNS, H., KLAGGE, B. (1997): Bankwesen und Regionalstruktur in Ungarn: Eine Analyse der Filialnetzstrukturen und -strategien aus regionalwirtschaftlicher Perspektive. Wien (= ISR-Forschungsberichte 16)

KereKes, G. (ed.) (1990) [1991, 1992, 1994, 1995]: Magyar Pénzügyi és Töszdei Almanach 1990 [1991, 1992-1993, 1993-1994, 1994-1995]. Budapest

KerEKES, G. (ed.) (1996) [1998]: Hungarian Financial and Stock Exchange Almanac 1995-1996 [1997-1998]. Budapest

KLAGGE, B. (1995): Strukturwandel im Bankwesen und regionalwirtschaftliche Implikationen: Konzeptionelle Ansätze und empirische Befunde. Erdkunde 49, 285-304

KLAGGE, B. (1997a): Ausländische Direktinvestitionstätigkeit im ungarischen und tschechischen Bankensektor: Empirische Analysen und Erklärung der Differenzen. Bank-Archiv 45 (8), 597-605

KlAGGE, B. (1997b): Internationalisierung des Bankwesens in Osteuropa: Die ausländischen Direktinvestitionstätigkeit im ungarischen und tschechischen Bankensektor im Spannungsfeld zwischen nationalen Bedingungen und der internationalen Niederlassungspolitik multinationaler Banken. Münster (= Wirtschaftsgeographie 12) 
KSH (ed.) (1998): A Magyar Köztársaság Helységnévkönyve: 1998, január 1. Budapest

Latour, B. (1993): We Have Never Been Modern. Cambridge

LATOUR, B. (1999): Pandora's Hope: Essays on the Reality of Science Studies. Cambridge, London

LENGYEL, I. (1994): The Hungarian Banking System in Transition. GeoJournal 32 (4), 381-391

LENGYEL, I. (1995): From Plan to Market: The Case of the Hungarian Banking System. In: TYKKYLÄINEN, M. (ed.): Local and Regional Development During the 1990s Transition in Eastern Europe. Aldershot, Brookfield, Hong Kong, Singapore, Sydney, 109-118

Leyshon, A. (1997): Geographies of Money and Finance II. Progress in Human Geography 21 (3), 381-392

Leyshon, A., ThrIfT, N. (1995): Geographies of Financial Exclusion: Financial Abandonment in Britain and the United States. Transactions of the Institute of British Geographers NS 20, 312-341

Leyshon, A., ThrifT, N. (1997): Money/Space: Geographies of Monetary Transformation. London, New York

MASSEY, D. (1984): Spatial Divisions of Labor: Social Structures and the Geography of Production. New York

Massey, D. (1999): Power-Geometries and the Politics of Space-Time: HettnerLecture 1998. Heidelberg

Meusburger, P. (1995): Spatial Disparities of Labour Markets in Centrally Planned and Free Market Economies: A Comparison Between Hungary and Austria in the Early 1980's. In: FLÜCHTER, W. (ed.): Japan and Central Europe Restructuring: Geographical Aspects of Socio-Economic, Urban, and Regional Development. Wiesbaden, 67-82

Murdoch, J. (1997): Towards a Geography of Heterogeneous Associations. Progress in Human Geography 21 (3), 321-337

NATIONAL BANK OF Hungary (ed.) (1991) [1994, 1998, 1999b]: Annual Report 1990 [1993, 1997, 1998]. Budapest

NATIONAL BANK OF Hungary (ed.) (1999a): The Hungarian Banking Sector: Developments in 1998. Budapest

NAtional BanK of Hungary (ed.) (1999c): The Payment Card Business in Hungary: Based on Figures for the First Half of 1999. Budapest

StATE BANKING SuPERVISION (ed.) (1991a): New Banking Act in Hungary I. December 1, 1991. Budapest

StAte BAnKIng Supervision (ed.) (1991b): New Banking Act in Hungary II. December 1, 1991. Budapest

StAte BANKIng SuPERVISION (ed.) (1997): New Legislation on Financial and Capital Market in Hungary 1997. Budapest

SzELÉNYI, E., URSPRUNG, J. (1998): The Hungarian Two-Tier Banking System: The First Eleven Years (1987-1997). Budapest 
SzÖKE, A. (1998): The Rural Bank: Past, Present and Future of Savings Co-operatives. In: KEREKES, G. (ed.): Hungarian Financial and Stock Exchange Almanac 1997-1998. Volume I. Budapest, 584-587

THRIFT, N. (1996): Spatial Formations. London

WARDENGA, U. (ed.) (2000): Transformationsforschung: Stand und Perspektiven: Beiträge einer wissenschaftlichen Tagung. Europa Regional 8 (3/4). Leipzig

WASS VON CZEGE, A. (1987): Wirtschaftsentwicklung und -system in Ungarn. Südosteuropa. Zeitschrift für Gegenwartsforschung 36 (7/8), 371-430 
